\title{
Palaeo-thermal and coalification history of Permo-Carboniferous sedimentary basins of Central and Western Bohemia, Czech Republic: first insights from apatite fission track analysis and vitrinite reflectance modelling
}

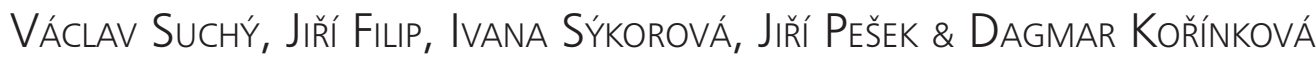

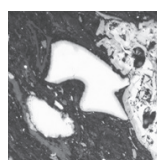

\begin{abstract}
Apatite fission track analysis (AFTA) and vitrinite reflectance (VR) modelling were integrated to reveal palaeothermal evolution of the Upper Carboniferous coal-bearing basins of Central and Western Bohemia. Thermal modelling using AFTA has shown that the Carboniferous sediments were subjected to maximum temperatures ranging from $\sim 75{ }^{\circ} \mathrm{C}$ in the SW to more than $\sim 120{ }^{\circ} \mathrm{C}$ in the NE, which generally concluded during pre-Triassic times. Thermal records show a gradual cooling between $\sim 280-180 \mathrm{Ma}$, followed by a long Mesozoic to Cenozoic Period of thermal stability, during which time, the sediments resided at constant temperatures of $\sim 50-75{ }^{\circ} \mathrm{C}$. From $\sim 30 \mathrm{Ma}$ onwards, accelerated cooling and erosion occurred, resulting in the present-day exposure of rocks on the surface. The EASY $\% \mathrm{R}_{\mathrm{o}}$ modelling of average VR values that range from $0.59 \% R_{r}$ in the $\mathrm{SW}$ to $0.77 \% R_{r}$ in the $\mathrm{NE}$, predicted maximum palaeo-temperatures ranging from $\sim 85{ }^{\circ} \mathrm{C}$ to $\sim 135{ }^{\circ} \mathrm{C}$, respectively; these were attained soon after sediment deposition. A coalification grade of about $0.40-0.50 \% R_{r}$ characteristic of sub-bituminous coals, was already completed during the late Carboniferous and/or early Permian times. Later post-Permian heating did not have any substantial impact on the maturation of Carboniferous organic matter. By combining VR thermal modelling with local stratigraphic information we provide evidence that the coalification process occurred very rapidly. A coalification grade of $\sim 0.40 \% R_{r}$ was attained during 2-4 m.y. after peat deposition, or even earlier. In addition, abundant sub-bituminous coal clasts embedded within the Carboniferous strata suggest that coalification proceeded close to the surface. These data collectively imply extremely high thermal gradients (around or above $200{ }^{\circ} \mathrm{C} / \mathrm{km}$ ) that must have prevailed during the Permo-Carboniferous thermal climax. The syn-sedimentary volcanic and/or igneous activity combined with effects of heat advection due to hot fluids circulating through the strata could have accounted for this dramatic geothermal setting, which had vanished by the end of the Palaeozoic Era. $\bullet$ Key words: coalification, organic matter diagenesis, geothermal gradient, heat flow evolution, Variscan orogeny, Bohemian Massif.
\end{abstract}

Suchý, V., Filip, J., SÝkorová, I., PeŠEk, J. \& KoŘínkovÁ, D. 2019. Palaeo-thermal and coalification history of PermoCarboniferous sedimentary basins of Central and Western Bohemia, Czech Republic: first insights from apatite fission track analysis and vitrinite reflectance modelling. Bulletin of Geosciences 94(2), 201-219 (9 figures, 2 tables). Czech Geological Survey, Prague. ISSN 1214-1119. Manuscript received October 31, 2017; accepted in revised form March 15, 2019; published online May 6, 2019; issued June 17, 2019.

Václav Suchý, Nuclear Research Institute, v. v. i., Academy of Sciences of the Czech Republic, Na Truhlár̆ce 39/64, 180 86 Prague 8, Czech Republic; suchy@tc.cz • Jiři Filip, Institute of Geology, Academy of Sciences of the Czech Republic, Rozvojová 269, 16500 Prague 6-Lysolaje, Czech Republic • Ivana Sýkorová, Institute of Rock Structure and Mechanics, Academy of Sciences of the Czech Republic, V Holešovičkách 41, 18209 Prague 8, Czech Republic • Jiři Pešek, Charles University Prague, Institute of Geology and Palaeontology, Albertov 6, 12843 Prague 2, Czech Republic • Dagmar Kořinková, Institute of Geology, Academy of Sciences of the Czech Republic, Rozvojová 269, 16500 Prague 6-Lysolaje, Czech Republic \& Faculty of Science, Charles University, Albertov 6, 12843 Prague 2, Czech Republic

During the last decade, a number of studies have applied the technique of apatite fission track (AFT) analysis (AFTA) to various geological formations in order to reconstruct their low-temperature thermo-chronologies, exhumation rates and/or landscape geomorphological evolution (see also Lisker et al. 2009, Green \& Duddy
2012 and Enkelmann \& Garver 2016 for reviews on AFTA applications to geology). With respect to the Bohemian Massif, most of these studies have concentrated on its peripheral zones, where the AFTA technique documented an intensive Mesozoic denudation (e.g. Hejl et al. 1997, 2003; Thomson \& Zeh 2000; Ventura \& Lisker 2003; 
Aramowicz et al. 2006; Danišík et al. 2010; Sobczyk et al. 2015). On the other hand, thermal studies of rocks forming the interior parts of the Bohemian Massif that yielded substantially older AFT ages (e.g. Vamvaka et al. 2013) have been limited so far to the Lower Palaeozoic and Neoproterozoic sediments of the Barrandian area in the central part of the Czech Republic (Glasmacher et al. 2002; Suchy et al. 2002; Filip \& Suchý 2004; Suchý et al. 2007, 2015).

In order to bridge this gap and to expand our knowledge of the low-temperature history of younger sedimentary formations from interior parts of the Bohemian Massif, we examined the apatite fission-track thermo-chronology of the Upper Carboniferous sediments that overlie Neoproterozoic and Lower Palaeozoic basement rocks in Central and Western Bohemia. In an attempt to achieve a deeper insight into the thermal history of these deposits, we combined the AFT technique with independent vitrinite reflectance kinetic modelling. The combination of these two techniques permitted the reconstruction of the palaeo-temperature record, extending deeper into the thermal past of the rocks, beyond the limits of the AFT technique alone.

Our data showed that the Carboniferous succession was subjected to an intense, but short-lived Variscan thermal event. An important by-product of our research was new evidence on the duration of the coalification process, which proceeded rapidly at a shallow burial level, being accelerated by highly elevated Variscan heat flows.

\section{Geological setting and previous studies}

A series of Late Palaeozoic coal-bearing basins - notably Plzeň, Manětín, Žihle, Kladno-Rakovník and MšenoRoudnice basins - occur in the central and western part of the Czech Republic, covering an area of about $6,000 \mathrm{~km}^{2}$ (Pešek et al. 1998; Fig. 1). These extensional depressions, filled with terrestrial Permo-Carboniferous deposits, developed in the interior of Variscan Europe, some $300-400 \mathrm{~km}$ to the south from the North Variscan Foredeep (Ziegler 1990, McCann et al. 2006). The tectonic nature of these basins was variously reported. Havlena (1982) suggested a model of an extensive asymmetric mega-graben that subsided into the Neoproterozoic crystalline basement, but according to later studies, the basins originated as wrench-fault - activated depressions triggered by oblique convergence of Gondwana and Baltica plates (Pašek \& Urban 1990).

In most basins the deposition began almost synchronously during the late Westphalian (near the DuckmantianBolsovian boundary) and lasted until the early Permian (Cisuralian) time. The depth of sedimentary fill preserved in individual basins varied from several tens of metres to

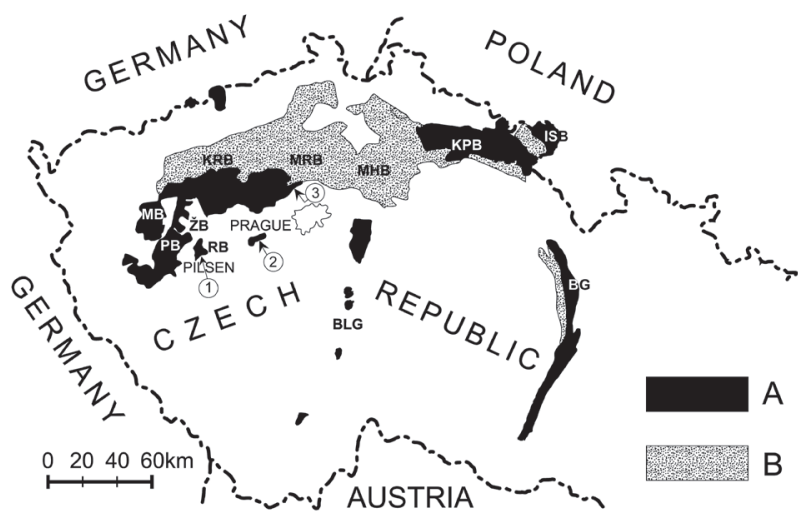

Figure 1. Schematic map showing the occurrence of Carboniferous terrestrial deposits and principal Carboniferous sedimentary basins in the Czech Republic (modified after Mísař et al. 1983); A - surface outcrops of Carboniferous deposits; B - Carboniferous deposits under the cover of younger sedimentary units. Abbreviations of Carboniferous basins: BG - Boskovice Graben; BLG - Blanice Graben; ISB - Intra-Sudetic Basin; KPB - Krkonoše Piedmont Basin; KRB - Kladno-Rakovník Basin; MB - Manětín Basin; MHB - Mnichovo Hradiště Basin; MRB - Mšeno-Roudnice Basin; PB - Plzeň Basin; RB - Radnice Basin; ŽB - Žihle Basin. Positions of the localities examined for their palaeo-thermal histories are also shown: 1 - Radnice-Ovčín; 2 - Nižbor (Stradonice, Lísek); 3 - Lobeč.

about $1,440 \mathrm{~m}$, depending on local variations in depositional history, subsidence rate, and the intensity of post-Carboniferous erosion. Sedimentation was often interrupted by numerous hiatuses and diastems, controlled by various tectonic and climatic events (i.e. Opluštil et al. 2016, Martínek et al. 2017). The sedimentary section is commonly subdivided into four lithostratigraphic formations, some of which are further separated into individual members. The two oldest formations (i.e. Kladno and Týnec formations) were dominated by fluvial sediments, while the lacustrine sediments were more widespread in the younger units (i.e. Slaný and Líně formations). The sandstones and claystones of the Kladno and Slaný formations were mostly grey and contained coal seams, while the two other units were mostly red-coloured and barren (Fig. 2). These sediments were deposited in variable continental settings ranging from extensive alluvial flood plains and incised river valleys to swamps and ephemeral lakes (Pešek 1996, 2001; Opluštil 2005; Lojka et al. 2016). The main sedimentary input into the basins was derived from local sources exposed in nearby upland areas, including some deeply eroded Variscan granitic intrusions and low-grade metamorphosed Neoproterozoic to Lower Palaeozoic rocks (Kukal 1983; Pešek 1996, 2004; Žák et al. 2018).

The coal rank of the Carboniferous coals increased with depth in many basins (Havlena 1964, Skoček 1976) where it ranged from $\sim 0.40$ to $1.11 \% R_{r}$ (Pešek 2001). Regional variations in coal rank between individual 
basins have been documented for coal seams of the Radnice Member, which range from $0.57-0.68 \% R_{r}$ in the West (the Plzeň Basin) up to $0.9-1.0 \% R_{r}$ in the East (the Kladno-Rakovník Basin), corresponding to the rank of bituminous coals (Pešek 1996, 2001). More detailed regional coalification studies have been carried out in the Plzeň Basin, where economically important coal seams were extensively mined in the past (Malán 1985, Pašek 1988). Substantially less coalified organic matter-rich Cretaceous (Cenomanian) sediments locally overlaid the Carboniferous strata. This structural relationship provides evidence that the main stage of coalification culminated before Cenomanian times (Havlena 1964).

In contrast to the stratigraphy and subsurface architecture of Carboniferous basins, which have been studied in detail, their thermal history, palaeo-heat flow regime and post-Variscan evolution have seldom been addressed. Šafanda et al. (1990) were the first to use vitrinite reflectance data from several deep boreholes, along with Buntebarth's (1982) calculation method in an attempt to estimate Carboniferous-Permian thermal gradients in these basins. More recently, Holub et al. (1997) applied the technique of time-temperature modelling of vitrinite reflectance and biomarker reactions to reveal the thermal history of the Mšeno-Roudnice Basin. Nevertheless, substantial uncertainties still persist about the original thickness, timing and magnitude of uplift, and the amount of erosion of the Carboniferous and Permian strata (see also Franců et al. 1998, Glasmacher et al. 2002, Filip \& Suchý 2004, Pešek \& Martínek 2012 and the discussions therein).

In the present study, we examine palaeo-thermal exposure and the time-temperature evolution of the Kladno Formation, which is the oldest stratigraphic unit of the Carboniferous succession. These strata are exposed on the surface at many places along the southern erosional margin of the basins in Central and Western Bohemia (Fig. 1).

The Kladno Formation, which comprises mostly grey, $360-415 \mathrm{~m}$ thick deposits, consists of two lithostratigraphic units - the Radnice Member and the Nýrany Member separated by a major depositional hiatus (Fig. 2). Sediments of the Radnice Member were deposited over eroded Lower Palaeozoic or Neoproterozoic basement rocks, during a period of significant tectonic activity. This is evidenced by abrupt facial changes and the variable thickness of Radnice sedimentary strata, which range from several metres to $279 \mathrm{~m}$. The dominant lithologies are arkoses and aleuropelites, but conglomerates, volcanic tuffs, and economically important bituminous coal seams also occur locally.

The Nýřany Member accumulated after a 3.6 m.y. long depositional break (Opluštil et al. 2016) that is reflected in a prominent disconformity between its basal sediments and

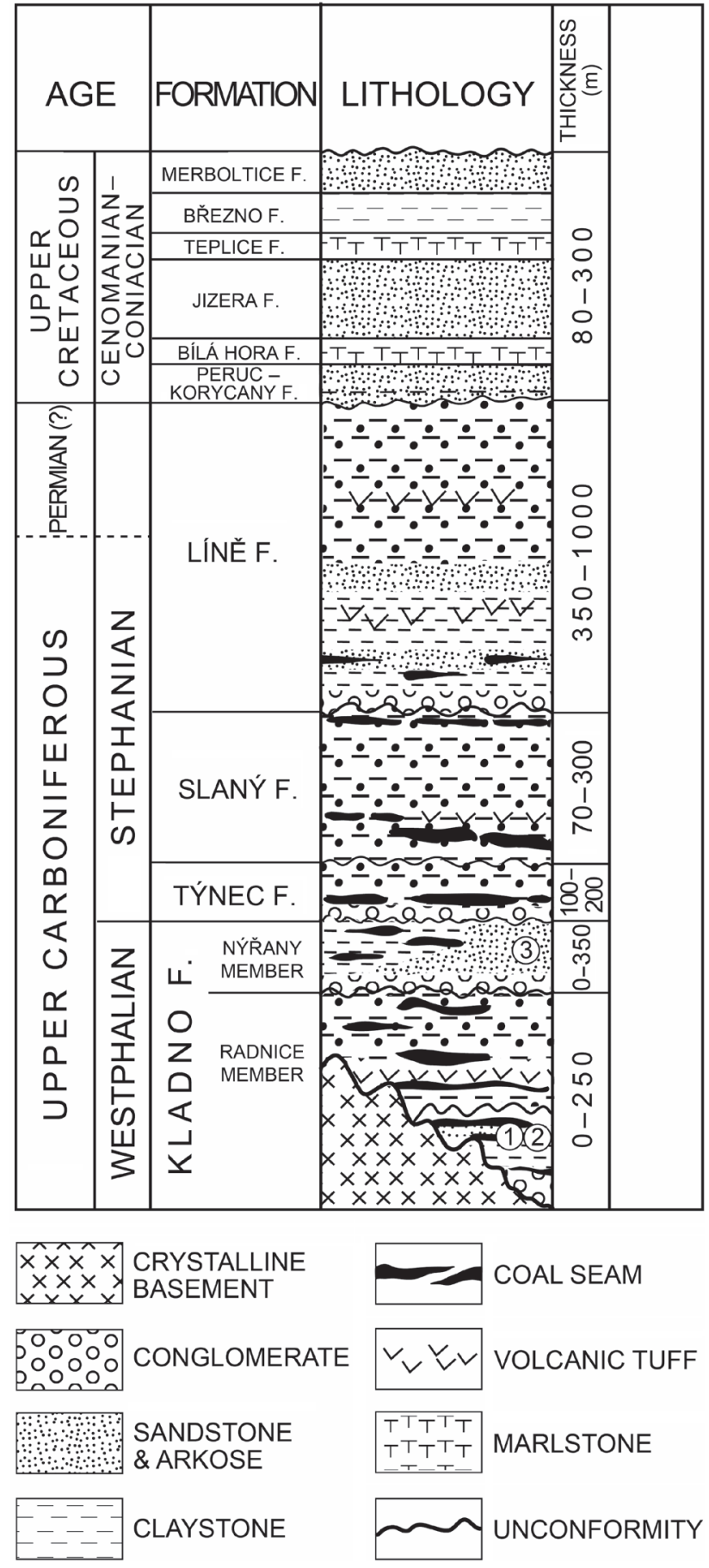

Figure 2. Schematic lithostratigraphy of Permo-Carboniferous (Holub 1982) and Cretaceous deposits for the central part of the Czech Republic (Čech et al. 1980). Stratigraphic positions of the samples are also plotted. Abbreviations: 1 - Radnice-Ovčín; 2 - Nižbor (Stradonice, Lísek); 3 - Lobeč; F. - Formation. See the text for details.

the underlying Radnice member. The average thickness of the Nýřany Member in the Kladno-Rakovník Basin was about $335 \mathrm{~m}$. The lowermost part of the unit consisted of conglomerates interbedded with arkoses and aleuropelites 
that graded upward into arkoses and aleuropelites locally intercalated with layers of volcanic tuffs and thin bituminous coal seams (see Pešek 2004 and Pešek \& Sivek 2016 for the details on local stratigraphy and lithology).

\section{Sample details}

The thermal exposure of Carboniferous sediments was investigated at three surface outcrops where the sediments yielded sufficient amounts of apatite grains for fission track analyses and allowed for simultaneous assessment of coaly fragments for respective vitrinite reflectance values. The absolute ages of the samples were calibrated toward the new chronostratigraphic timetable for Central and Western Bohemian Carboniferous basins (Opluštil et al. 2016) as 314 Ma for Radnice-Ovčín and Nižbor samples, and $307 \mathrm{Ma}$ for Lobeč sample, respectively.

The sample Radnice-Ovčín came from a layer of a finegrained kaolinite-rich volcanic tuff (the Bělka Horizon) of the Radnice Member (Fig. 3A). The sediment, which yielded a rich population of authigenic apatite grains, was taken from the wall of an abandoned coal mine situated to the south of Radnice (see Němejc 1953 and Opluštil et al. 2009 for the details on lithology and stratigraphy of this locality). Vitrinite reflectance measurements were made on coal particles taken from the Upper Radnice Coal Seam, which crops out approximately $10 \mathrm{~m}$ above the Bělka Horizon.

The Nižbor sample (Stradonice, Lísek) was collected from the Radnice Member. These deposits belonged to the lowermost part of the Carboniferous succession, which fills the Lísek erosional remnant, one of small, tectonically-constrained relict outliers of Carboniferous deposits that were preserved between Prague and Pilsen (Pešek \& Martínek 2012). The sampling point was situated in a steep gorge on the right bank of the Berounka river, about $3 \mathrm{~km}$ to the SE of Nižbor (see Němejc 1953 and Holub \& Obrhel 1967 for details). Apatite grains were extracted from the beds of coarse-grained conglomerates with arkose matrices. Thin coal seams and coaly claystone beds intercalating with the arkose provided vitrinite-rich materials sufficient for reflectance measurements.

The Lobeč sample was taken from coarse-grained arkoses stratigraphically belonging to the middle part of the Nýřany Member (Fig. 3B). The sampling point was located at the foothill of the Lobeč cliffs, exposed along the Vltava river at the northern periphery of Kralupy nad Vltavou (see also Opluštil et al. 2005 for geological details of this locality). While arkose sandstone itself provided a sufficient quantity of recycled detrital apatite grains, the partings of coaly claystone inter-bedded with arkose were rich in particles of dispersed organic matter suitable for reflectance studies.
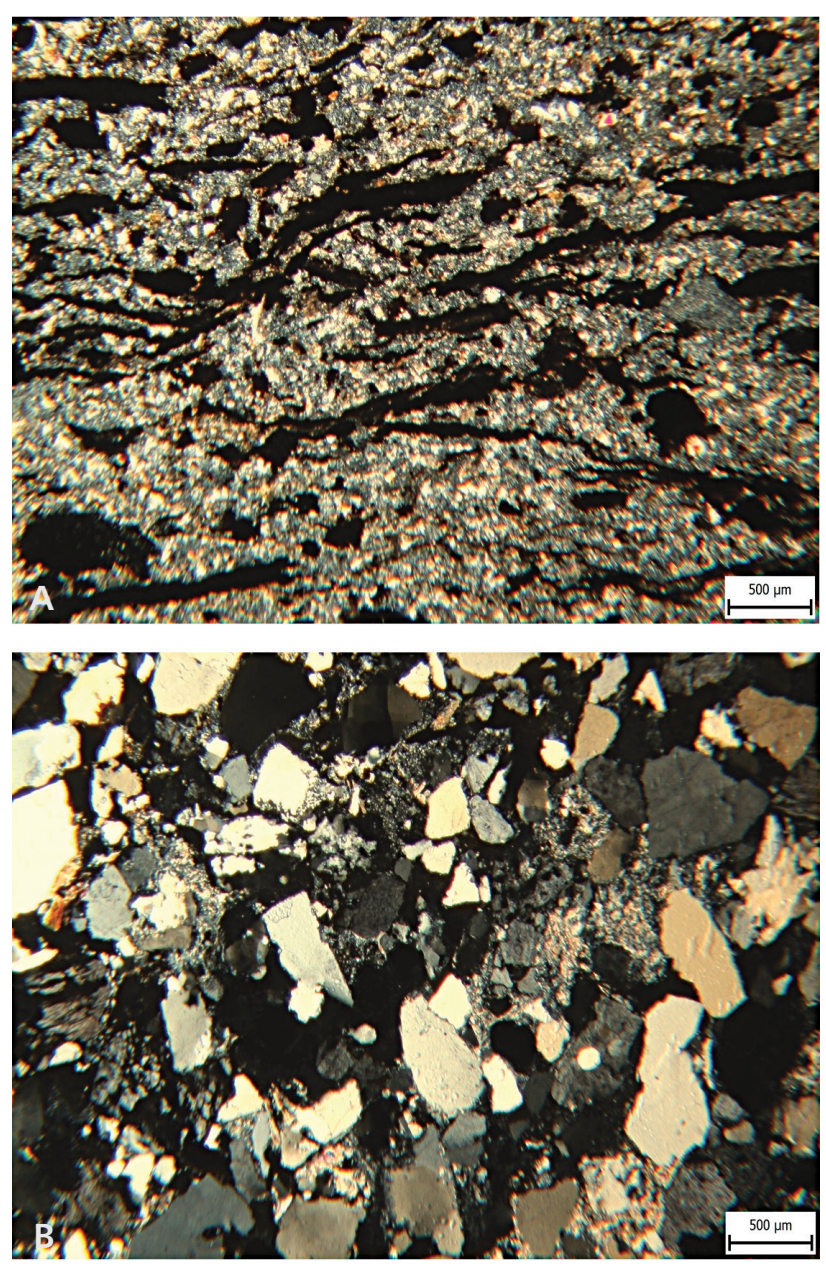

Figure 3. Photomicrographs showing aspects of representative Carboniferous apatite-bearing sediments (partlially crossed polars). $\cdot$ A intensely kaolinized volcanic tuff (the Bělka Horizon) of the Radnice Member. The dark opaque seams and spots arranged parallel to bedding are coalified vegetal fragments. - B - coarse-grained arkose from the Nýřany Member, the Lobeč cliffs. Main rock components are angular and sub-rounded quartz and feldspar grains cemented by clay minerals. Some feldspar grains were partly replaced by sericite forming minute bright crystals.

\section{Methods}

\section{Apatite fission track analysis (AFTA) and modelling}

Apatite fission track (AFT) analysis is a technique for defining the thermal history of sedimentary rocks, including palaeo-temperatures and semi-quantitative estimates of palaeo-temperatures over time (Storzer \& Selo 1984, Naeser et al. 1989). During the past 40 years, the method has gradually evolved into one of the most powerful tools to reconstruct the low-temperature thermal history of rocks, especially below $\sim 120^{\circ} \mathrm{C}$, for tracks in apatite. The AFT analysis has been established as 
a particularly important instrument for basin analysis and hydrocarbon exploration because the apatite annealing temperatures between 60 and $120{ }^{\circ} \mathrm{C}$ essentially coincide with temperatures for liquid hydrocarbon generation (Armstrong 2005).

In uranium-rich apatite crystals, narrow damage trails (i.e. fission tracks) are formed by swift heavy ions ejected during spontaneous nuclear decay of ${ }^{238} \mathrm{U}$. These tracks can be enlarged by chemical etching and counted using an optical microscope (Fig. 4). Track length distribution, in combination with apparent fission track ages, allows one to discriminate between different thermal histories, but proper interpretation of the data requires a complex mathematical treatment. Several software solutions have therefore been developed to compute thermal histories from AFT age and track length data (e.g. Laslett et al. 1987, Crowley et al. 1991; see also Armstrong 2005 for a review of the models). More recent overviews of fission track analysis techniques, including fundamentals of the method, have been provided by Gallagher et al. (1998), Gleadow et al. (2002), Tagami \& O'Sullivan (2005), Lisker et al. (2009), Green \& Duddy (2012) and Wagner \& Van Den Haute (1992).

Apatite grain concentrates were obtained from $\sim 7 \mathrm{~kg}$ rock samples using the standard heavy mineral liquid separation technique (Povondra \& Ulrych 1988). The grains were mounted in Epofix ${ }^{\circledR}$, polished and etched in $2.5 \% \mathrm{HNO}_{3}$ for 70 seconds to reveal the fission tracks. The external detector method (Wagner \& Van Den Haute 1992) was applied for fission track analysis. A lowuranium muscovite detector (Jahre GmbH Wilhelmshaven, Germany) was fixed on a polished surface and stacked in an irradiation cassette with a $\mathrm{CN} 5$ glass neutron dosimeter. The cassette was irradiated with thermal neutrons in the TRIGA Mk. II Research Reactor at the Oregon University. A nominal fluence of thermal neutrons of $8.14 \times 10^{15} \mathrm{~cm}^{-2}$ was reached. Densities and lengths of spontaneous and induced tracks were measured by an Axioplan 3 (Zeiss) microscope coupled with an AUTOSCAN ${ }^{\mathrm{TM}}$ stage. The mean chloride content of apatite grains (e.g. Barbarand et al. 2003, Green \& Duddy 2012) was determined using a CAMECA SX 100 Electron Micro Analyser. Fission track ages were calculated using the Zeta calibration factor according to Hurford \& Green $(1982,1983)$. As age standards, apatite samples from Fish Canyon volcanic tuff, and Durango and Mount Dromedary intrusive complexes were used. The measured fission track densities were treated using the age-equation provided by Trackscan software (Tab. 1).

The thermal history of the rocks (T-t paths) was computed using the AFTSolve program (Donelick \& Ketcham 1998; Ketcham et al. 2000, 2003, 2007; Ketcham $\&$ Apatite to Zircon, Inc. 2007), which uses the multikinetic annealing model (Carlson et al. 1999, Donelick
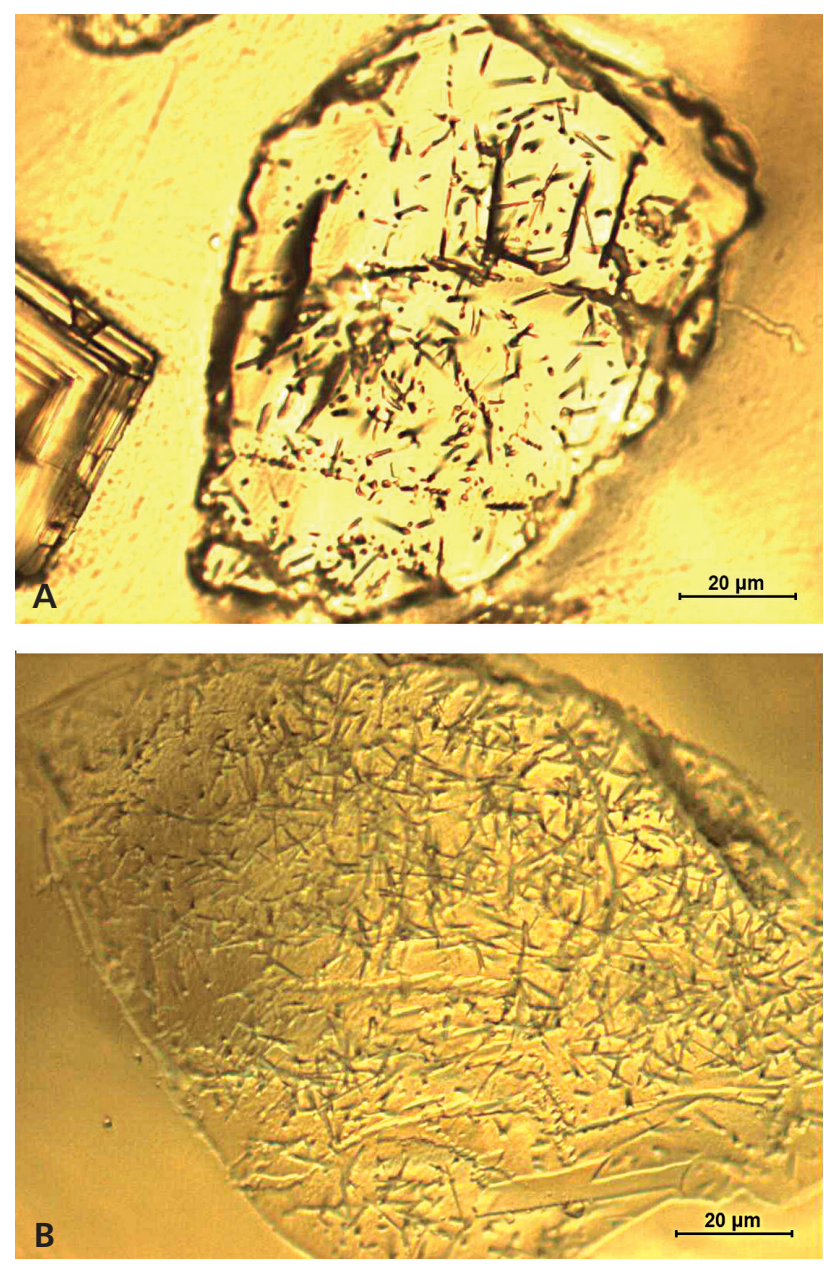

Figure 4. Microphotographs of fossil fission tracks in apatite grains separated from the Carboniferous sediments. Fission tracks were revealed by etching in $2.5 \% \mathrm{HNO}_{3} \cdot \mathrm{A}$ - angular authigenic apatite grain from the volcanic tuff (the Bělka Horizon) of the Radnice Member, Radnice-Ovčín quarry. The majority of linear features in the image are fission tracks. The difference in width of the tracks is due to a difference in etching rate that depends on crystallographic orientation. The latter is higher in the direction parallel to the c-axis. $-\mathrm{B}$ - subrounded detrital apatite grain from the arkose conglomerate, the Radnice Member, Nižbor. A number of fossil fission tracks can be recognized on the basal face of the crystal.

et al. 1999, Ketcham et al. 1999). This model takes into account the variability in chemical kinetics between different apatite populations, including their chlorine content, which is known to exert a significant control on fission track annealing rates in apatite (e.g. Green \& Duddy 2012 and the references therein). Chlorine contents are measured in every apatite grain, in which either age or fission-track length data are collected, and the AFTSolve model explicitly takes into account the influence of these $\mathrm{Cl}$ contents on annealing rates. This is one of the key advantages of the AFTSolve program that differs from other AFTA methods suggested by the end of the last century for interpretation of AFTA data. 
Table 1. Analytical results of apatite fission track analysis for the samples from Central and Western Bohemian Carboniferous basins. Abbreviations: $\rho_{S}$-spontaneous track density of a sample; $N_{S}$ - number of tracks counted to determine $\rho_{S} ; \rho_{i}$ - induced track density measured in a muscovite external detector; $N_{i}$ - number of tracks counted to determine $\rho_{i} ; n$ - number of counted grains; $P\left(\chi^{2}\right)$ - Poisson distribution test at $95 \%$ confidence level; $T L$ - mean length of horizontal confined fission tracks with standard deviation in all crystallographic orientations; $N$ - number of measured confined tracks; $\sigma$-standard deviation for the length distribution of confined fission tracks; $\mathrm{Cl}$ - chlorine content in studied apatite grains.

\begin{tabular}{|c|c|c|c|c|c|c|c|c|c|c|}
\hline $\begin{array}{l}\text { Sample } \\
\text { code }\end{array}$ & Locality & Lithology & $\begin{array}{l}\text { AFT-age } \\
{[\mathrm{Ma}+1 \sigma]}\end{array}$ & $\begin{array}{c}\rho_{\mathrm{s}}\left(\mathrm{N}_{\mathrm{s}}\right) \\
{\left[\times 10^{6} \mathrm{~cm}^{-2}\right]}\end{array}$ & $\begin{array}{c}\rho_{\mathrm{i}}\left(\mathrm{N}_{\mathrm{i}}\right) \\
{\left[\times 10^{6} \mathrm{~cm}^{-2}\right]}\end{array}$ & $\mathrm{n}$ & $\begin{array}{c}\mathrm{P}\left(\chi^{2}\right) \\
{[95 \%]}\end{array}$ & $\begin{array}{c}\mathrm{TL}(\mathrm{N}) \\
{[\mu \mathrm{m}]}\end{array}$ & $\begin{array}{c}\sigma \\
{[\mu \mathrm{m}]}\end{array}$ & $\mathrm{Cl}$ \\
\hline $\mathrm{K} 3$ & Lobeč & arkose & $204 \pm 25$ & $4.77(1360)$ & 3.19 (939) & 6 & fail & $11.6(90)$ & 1.8 & $<0.1$ \\
\hline L2 & Nižbor & arkose & $172 \pm 17$ & $5.85(5482)$ & $4.42(4219)$ & 20 & fail & $12.5(154)$ & 1.5 & $<0.1$ \\
\hline H11 & Radnice-Ovčín & volcanic tuff & $264 \pm 7$ & $6.89(6332)$ & $7.10(6528)$ & 20 & fail & $12.2(94)$ & 1.8 & $<0.1$ \\
\hline
\end{tabular}

The Monte Carlo method was applied to test 10,000 to 20,000 possible $T$ - $t$ paths (Ketcham et al. 2000). During the modelling process, the temperature and time constraints were kept at the minimum. Only the minimum temperature above the total annealing temperature of the most resistant apatite species, the sample age and the surface temperature of the sample from which apatite was collected were introduced as the earliest and final $T-t$ constraints, respectively (e.g. Ketcham et al. 2000). Further details on the modelling process can be found elsewhere (Filip \& Suchý 2004).

\section{Vitrinite reflectance (VR) measurement, modelling, and its integration with the AFTA data}

The technique of vitrinite reflectance measurement is now commonly used to determine the thermal maturity of coal and hydrocarbon source rocks ranging from low grade diagenesis to very low grade metamorphism, i.e. from $\sim 40{ }^{\circ} \mathrm{C}$ to $\sim 400{ }^{\circ} \mathrm{C}$ (Hunt 1979 , Tissot \& Welte 1984; see Teichmüller 1987, Suarez-Ruiz et al. 2012, HartkopfFröder et al. 2015, Ferreiro Mählmann \& Le Bayon 2016 for reviews). The increase in VR is dependent on many parameters, including temperature, geologic time, fluid chemistry, pore fluid pressure, oil content and degree of tectonic deformation (e.g. Hood et al. 1975; Barker \& Pawlewicz 1994; Huang 1996; Dalla Torre et al. 1997; Suchy et al. 1997; Le Bayon et al. 2011, 2012), but the influence of maximum temperature and duration of heating are the most important (Teichmüller 1987, Mukhopadhyay 1992). The technique of VR measurement has significant advantages over other geo-thermometers, such as clay minerals, fluid inclusion, and fission track annealing in that the vitrinite is commonly present in many sedimentary rocks, its reflectance is irreversible and rapidly stabilizes in response to the maximum temperature to which the entire system has been exposed (Price 1983, Barker \& Pawlewicz 1994; see also Tobin \&
Claxton 2000 and the references therein). Compared with mineral indices, vitrinite reacts faster to heating (Ferreiro Mählmann et al. 2012, Potel et al. 2016).

Using reaction kinetics (Arrhenius equations), the relationship between VR, rock temperature, and heating time can be used to reconstruct geothermal history (Buntebarth \& Stegena 1986, Robert 1988). Early kinetic models of vitrinite maturation applied to petroleum exploration used a simple concept in which the rate of maturation doubles every $10{ }^{\circ} \mathrm{C}$ (Lopatin 1971). Since then, a number of more sophisticated kinetic models of vitrinite maturation have been proposed, as reviewed by Waples (1980, 1989), Wood (1988), Morrow \& Issler (1993), Le Bayon et al. (2012), Burnham et al. (2017) and Nielsen et al. (2017).

The kinetics of vitrinite reflectance (VR) is generally similar to that of fission track annealing in apatite (Burnham \& Sweeney 1989). This makes VR an ideal complement to the AFTA technique when applied to sedimentary sequences (see Green \& Duddy 2012 and the references on combined AFTA/VR studies therein). The combination of AFTA and VR data has two distinct advantages (Bray et al. 1992, Arne \& Zentilli 1994, Duddy et al. 1998): firstly, the two techniques, which are mutually independent, can be considered as maximum recording thermometers. This provides a valuable check on maximum palaeo-temperatures. AFTA data give palaeo-temperature estimates of up to a maximum value, usually around $120{ }^{\circ} \mathrm{C}$, at which total annealing occurs in apatite, whereas VR continues to react to substantially higher temperatures. Thus, VR combined with AFTA data can be of great assistance in confirming or revealing thermal events, which may not be confidently defined by AFTA alone (e.g. Green \& Duddy 2012, Green et al. 2002). Secondly, the VR variations themselves bear no time information at all, but using the Sweeney \& Burnham (1990) model, an agreement can be achieved between observed and predicted VR values through the thermal history time, using the framework provided by AFTA data. This is particularly important, because data from 
either technique alone might be viewed with discretion, but when two independent techniques provide comparable palaeo-temperatures, the conclusions can be regarded as reliable.

Reflectance data were collected on macroscopic coaly particles from thin coal seams (Radnice-Ovčín and Stradonice) and vitrinite fragments dispersed in sedimentary rocks (Lobeč). The samples were cut and polished normal to bedding and studied using an Olympus BX51 optical microscope equipped with a Zeiss Photomultiplier MK3 under both reflected-light and fluorescence regimes using lenses with $\times 40$ and $\times 100$ magnifications. The Pelcon point counter was used for maceral analysis. The determinations of vitrinite, liptinite and inertinite group macerals were executed following the recent ICCP recommendations (i.e. ICCP 1998, 2001; ISO 7404-3 2009; Taylor et al. 1998; Pickel et al. 2017). Random reflectance values of organic matter $\left(R_{r} \%\right)$ were determined using the Spectra Vision software. Sapphire $(R=0.596 \%)$, yttrium-aluminium-garnet $(R=0.894 \%)$, and N-LASF46A $(R=1.309 \%)$ reflectance standards were used for calibration of measurements according to ISO 7404-5 (2009) and Taylor et al. (1998). The number of reflectance measurement points $(n)$ varied from 20 to 100 measurements per sample $\left(n_{\text {average }}=82\right)$, with standard deviations $(\sigma)$ ranging from 0.04 to 0.09 ; Tab. 2).

The VR modelling was applied to resolve three mutually interrelated tasks: (1) to reconstruct early stages of thermal history of the samples including maximum palaeo-temperatures that cannot be estimated by the AFTA method alone, (2) to provide an independent check of AFTA-derived $T-t$ paths of the samples, and (3) to estimate the timing and duration of coalification. The VR modelling was used to reconstruct early stages of the thermal evolution of L2 - Nižbor and K3 - Lobeč samples, which occurred before the annealing of its apatite fission tracks. For H11 - Radnice-Ovčín sample, which was exposed to temperatures $<120^{\circ} \mathrm{C}$, the VR modelling was employed merely as an independent check of its $T$ - $t$ path derived from AFT data.

The time-temperature evolution of vitrinite was simulated by repeated iterative runs of the EASY $\% \mathrm{R}_{\mathrm{o}}$ program (Sweeney \& Burnham 1990). This vitrinite maturation model applies the kinetic variables, activation energy, and frequency factors estimated using different heating rates during Rock-Eval pyrolysis (Fig. 5). It can be conveniently implemented on a spreadsheet, or in the form of a small program on a personal computer. The model can be used with any type of thermal history including non-deposition, uplift and cooling, and for VR values ranging from 0.3 to $4.5 \% R_{r}$, and for heating rates ranging from those in the laboratory $\left(1{ }^{\circ} \mathrm{C} /\right.$ week $)$ to those in slowly subsiding basins $\left(1^{\circ} \mathrm{C} / 10\right.$ m.y.). For each sample studied, multiple combinations of temperatures and heating times were

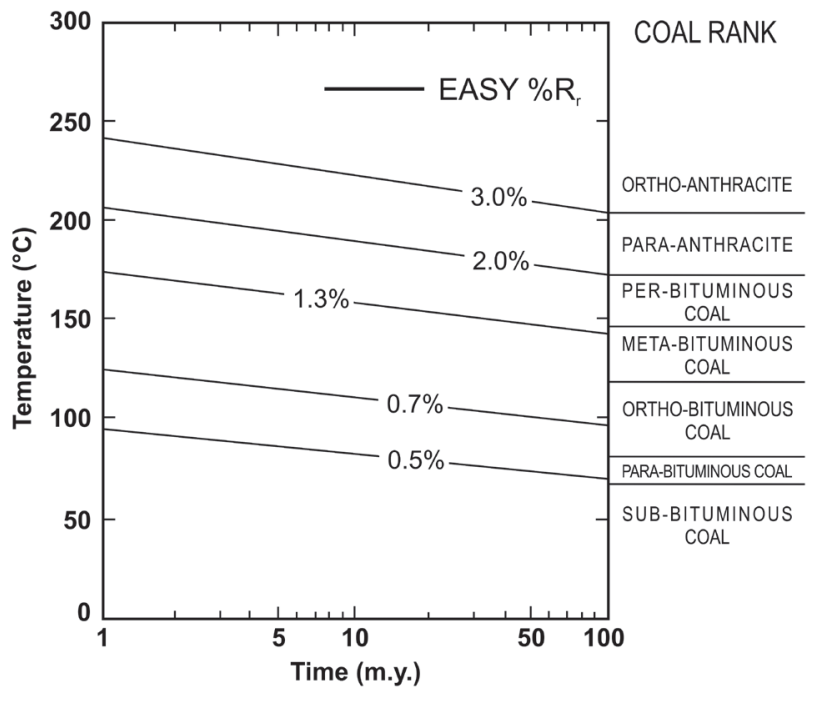

Figure 5. Nomogram of vitrinite reflectance $v s$. exposure time and maximum temperature calculated using EASY\% $\mathrm{R}_{\mathrm{o}}$ (after Sweeney \& Burnham 1990, with modifications). Correlation between vitrinite reflectance and coal rank of seam coals (after International Classification of in-Seam Coals 1998) is also shown.

tested until a reasonable fit with the measured $R_{r}$ values was reached. The original input data (i.e. temperatures, heating times) and resulting VR values obtained during individual $\mathrm{EASY} \% \mathrm{R}_{\mathrm{o}}$ runs are available on request from the first author as Excel spreadsheets.

We deliberately limited our study to a simple reconstruction of thermal evolution of the samples, without making any attempt to retrieve its burial and/or subsidence histories. This minimalistic approach was primarily caused by a very limited amount of reliable information that we were able to collect on the thicknesses of stratigraphic overburden at the localities under study, as well as on organic matter reflectance values from overlying Cretaceous sediments. There is a hope that in the future, when more background data are available, full-scale comprehensive regional study will be possible, including a detailed burial history reconstruction of Carboniferous sediments.

\section{Results and Interpretations}

\section{Apatite fission track analysis}

Apatite fission track analysis (AFTA) of all three samples revealed that its confined tracks of apatite grains were shortened from their initial length of $16.3 \mu \mathrm{m}$ to about $11.6 \mu \mathrm{m}$ (Tab. 1). This implies that the samples experienced a partial (H11 - Radnice-Ovčín) to complete annealing (L2 - Nižbor and K3 - Lobeč) during their palaeothermal histories. In order to fully elucidate the meaning 
H11 - RADNICE-OVČÍN

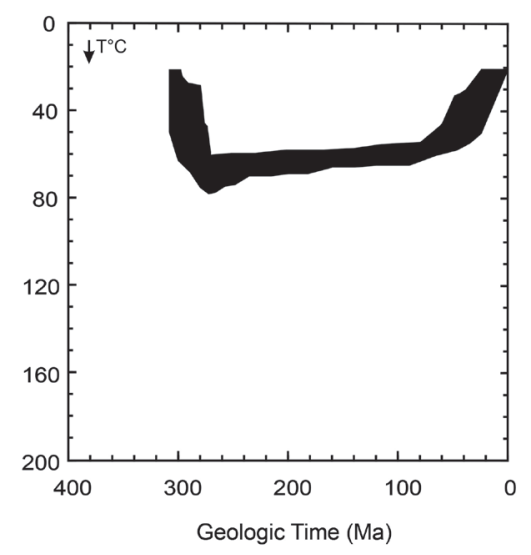

L2 NIŽBOR

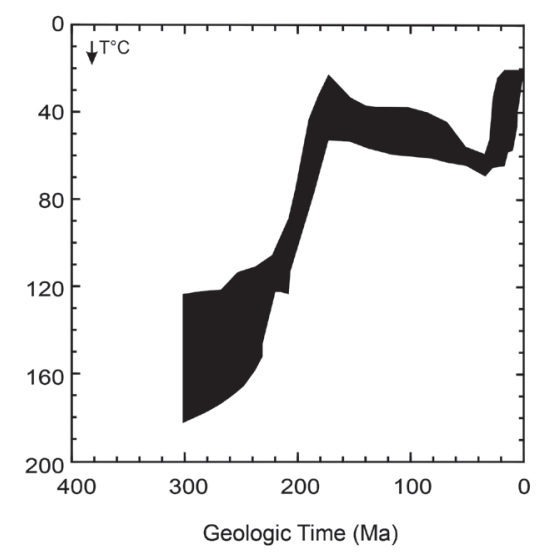

K3 LOBEČ

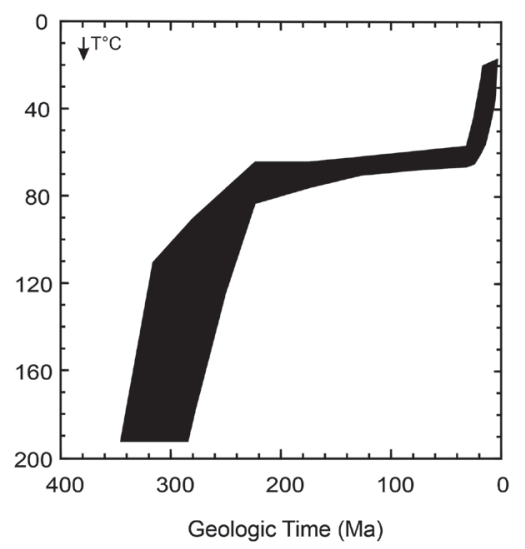

Figure 6. Results of reverse thermal modelling of the apatite fission tracks for three samples from Central and Western Bohemian Carboniferous basins using the AFTSolve software. The black areas encompass all good and best-fit $T-t$ paths with a probability of more than $90 \%$. Note that temperatures in excess of $120^{\circ} \mathrm{C}$ represent a software artefact, with no geological meaning (see Ketcham et al. 2000 for AFTSolve programme details.).

of the data, thermal histories of the samples were modelled based on available thermo-chronological constraints (Fig. 6).

The H11 - Radnice-Ovčín sample of volcanic tuff never entered into the zone of complete annealing. As a consequence, the sample preserves a complete $T-t$ record from the moment of apatite grain deposition until recent time. It shows that the sediment was intensely heated soon after deposition and exposed to maximum palaeotemperatures of about $75{ }^{\circ} \mathrm{C}$ that culminated during the early Permian time. Starting from $\sim 280$ Ma till about $60 \mathrm{Ma}$, the rock experienced a long period of thermal stagnation, during which, it resided in a zone of stable temperatures of about $60-70{ }^{\circ} \mathrm{C}$. This part of the thermal history of the sample correlates well with the known regional sedimentary record, which evidences low sedimentation rates and/or non-deposition over a substantial part of the Mesozoic (e.g. Malkovský 1979). Rapid cooling of the sediments began about $40 \mathrm{Ma}$. This thermal event can be paralleled with a major structural inversion that has affected the interior of the Bohemian Massif since the Paleogene period (Malkovský 1979, 1987; see also Ziegler et al. 1999, Zeman et al. 2000, Filip \& Suchý 2004).

The modelling of T-t paths for Nižbor (L2) and Lobeč (K3) samples showed that these sediments were subjected to temperatures in excess of $\sim 120^{\circ} \mathrm{C}$, which resulted in the total annealing of apatite grains before $\sim 200-260 \mathrm{Ma}$ (Permian to Early Jurassic).

Unfortunately, the AFTA method alone does not allow for the reconstruction of thermal evolution preceding annealing. The post-annealing thermal history of the samples, however, can be reconstructed and it shows that the rocks experienced two-stage cooling (Fig. 6). The first cooling episode occurred when the sediments ascended from the zone of total annealing. This temperature drop was probably due to post-Variscan structural inversion and erosion that removed a part of CarboniferousPermian sequence in the area (e.g. Holub et al. 1997), but a steep decrease in regional heat flow during the Permian to Jurassic period may also have been involved (see also vitrinite reflectance modelling below). This first cooling episode terminated at 180-220 Ma (Jurassic-Triassic). Since then, until about 20-40 Ma, the thermal histories of both samples were essentially similar to those of the Radnice-Ovčín (H11) sample, including a period of prolonged Mesozoic to Cenozoic thermal stagnation at $60-70{ }^{\circ} \mathrm{C}$, followed by fast cooling to surface temperature during the Paleogene-Neogene time. A minor temperature increase that can be seen in the T-t path of L2 Nižbor sample for a period around 90-40 Ma can be probably attributed to heating beneath several hundred metres of overburden of Cretaceous to (?)Paleogene sediments that may subsequently have been removed. Some previous studies have already indicated that the Cretaceous sedimentation in the area may have continued locally after the Santonian, and a thickness of more than to 1,000 metres of sediments may have been eroded from the top of the existing basin fill (e.g. Uličný \& Franců 1996, Holub et al. 1997).

\section{Vitrinite reflectance measurement and modelling}

Vitrinite reflectance values ascertained in the Carboniferous sediments are presented in Tab. 2. The values of random reflectance $\left(R_{r}\right)$ of vitrinite ranged from 0.53 in 
the SW (Radnice-Ovčín) to $0.83 \% R_{r}$ in the NE (Lobeč). These reflectance values are generally indicative of parabituminous to ortho-bituminous medium-rank coals (International Classification of in-Seam Coals 1998).

The coal samples taken from the Upper Radnice Coal Seam at the Radnice-Ovčín quarry represent dull-banded coal with a low content of mineral admixtures (Fig. 7A). The coal consists of common vitrinite-group macerals, with subordinate liptinite and inertinite particles. The dominant vitrinite maceral present is colotelinite on which the reflectance measurements were performed.

Thin coal seams and dark claystone partings sampled at Nižbor yielded a similar assemblage of organic constituents dominated by vitrinite-group macerals. Colotelinite and less abundant colodetrinite were identified as the most common types of vitrinite group materials in these samples, along with subordinate particles of liptinite and inertinite groups (Fig. 7B).

Dark coaly claystone samples from Lobeč cliffs were found to be relatively poor in recognizable organic particles. Scarce detrital vitrinite and inertinite fragments were found dispersed in a clayey matrix or embedded in secondary quartz cement (Fig. 7C, D). Additional details on VR measurements and organic-petrological characteristics of individual samples are summarized in Tab. 2.

Figure 8 shows the calculated VR values and the respective palaeo-temperatures of individual samples as they evolved from the deposition time to the present. At Radnice-Ovčín, the modelling of an average VR value
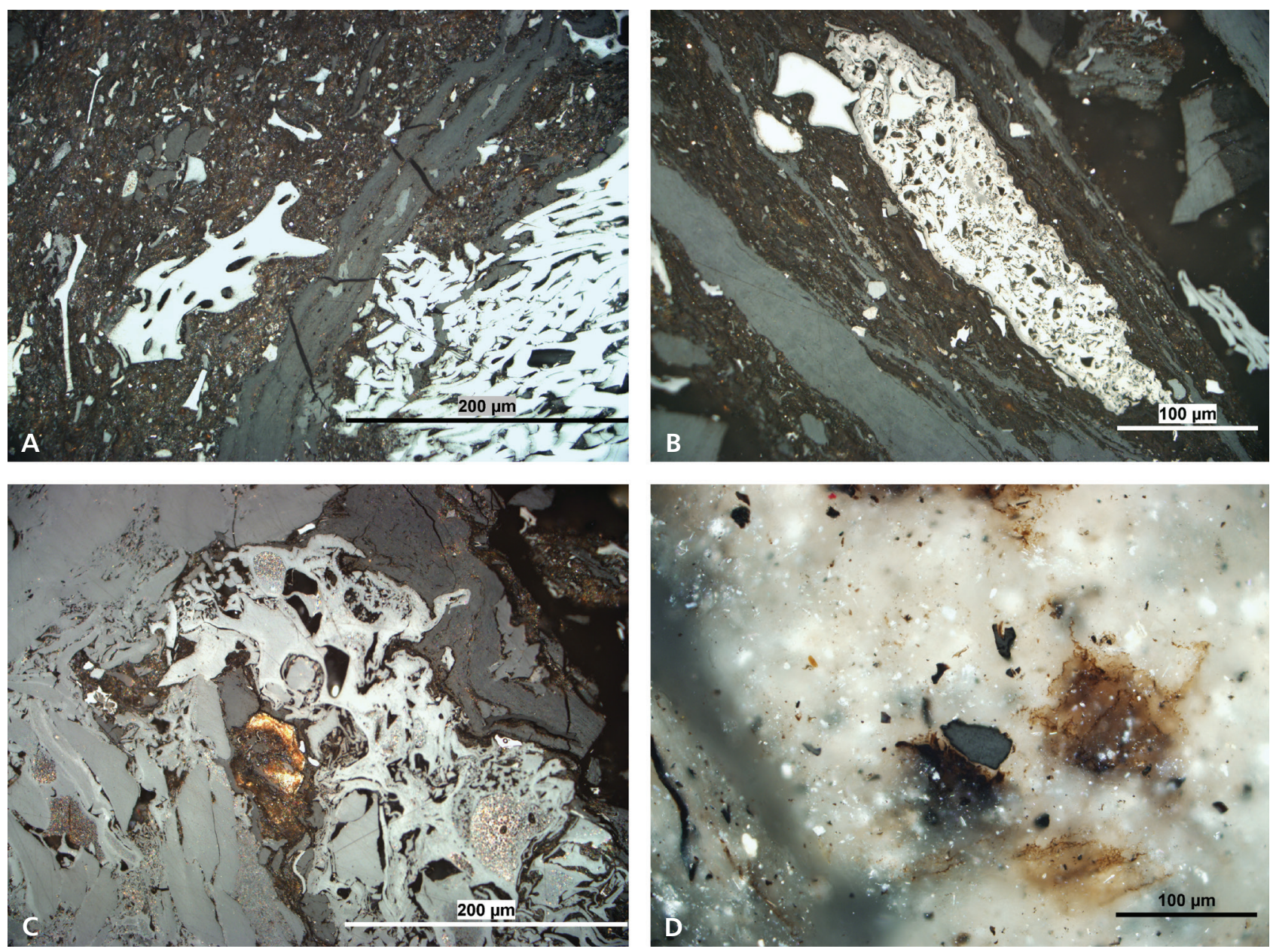

Figure 7. Microphotographs showing characteristic types of organic macerals recognised in Carboniferous sediments. Microphotographs were taken on polished rock surfaces under oil immersion, and normal reflected light. - A - elongated band of medium-grey vitrinite (colotellinite) surrounded by bright whitish grains of inertinite materials (fusinite and semifusinite). Detrital matrix is rich in small liptinite fragments, finely disseminated clay minerals and vitrinite and inertinite fragments. The Upper Radnice Coal Seam, Radnice-Ovčín quarry. • B - elongated medium grey bands of vitrinite (colotellinite) in association with brightly white reflecting intertinite-group particles (semifusinite, macrinite and inertodetrinite) bound in a finegrained detrital matrix rich in liptinite fragments. Nižbor. $\cdot \mathrm{C}$ - medium-grey vitrinite fragments (left) and a larger grey inertinite particle (centre). Brown-coloured small grains are liptinites. Lobeč. $\bullet$ D - small medium-grey vitrinite particles embedded in massive whitish quartz cement. Diffusely outlined, rusty brown bodies are clay minerals. Lobeč. 
Table 2. Organic-petrological data of Carboniferous coal-bearing sediments. See text for details.

\begin{tabular}{|c|c|c|c|c|c|c|c|c|c|}
\hline $\begin{array}{l}\text { Sample } \\
\text { No. }\end{array}$ & Locality & $R_{r}(\%)$ & $\sigma$ & $\begin{array}{c}R_{r \min }-\mathrm{R}_{\mathrm{rmax}} \\
\quad(\%)\end{array}$ & $\begin{array}{l}\text { Number of } \\
\text { measured } \\
\text { points }(n)\end{array}$ & $\begin{array}{l}\text { Vitrinite } \\
\text { (vol. \%) }\end{array}$ & $\begin{array}{l}\text { Liptinite } \\
\text { (vol. \%) }\end{array}$ & $\begin{array}{l}\text { Inertinite } \\
\text { (vol. \%) }\end{array}$ & $\begin{array}{c}\text { Minerals } \\
\text { (vol. \%) }\end{array}$ \\
\hline 98/089 & Radnice-Ovčín & 0.53 & 0.04 & $0.48-0.60$ & 100 & 62.1 & 15.8 & 12.6 & 9.5 \\
\hline $03 / 249$ & Radnice-Ovčín & 0.58 & 0.09 & $0.48-0.67$ & 100 & 50.2 & 30.8 & 11.4 & 7.6 \\
\hline \multirow[t]{2}{*}{$98 / 085$} & Radnice-Ovčín & 0.65 & 0.08 & $0.56-0.72$ & 100 & 46.1 & 22.0 & 18.8 & 13.1 \\
\hline & $\begin{array}{l}\text { Radnice-Ovčín } \\
\text { (average value per locality) }\end{array}$ & 0.59 & & & & & & & \\
\hline $43 / 211$ & Nižbor & 0.73 & 0.08 & $0.65-0.80$ & 60 & 50.6 & 8.2 & 10.5 & 30.7 \\
\hline 98/086A & Nižbor & 0.63 & 0.08 & $0.58-0.74$ & 100 & 42.2 & 24.6 & 15.1 & 18.1 \\
\hline \multirow[t]{2}{*}{ 98/086B } & Nižbor & 0.72 & 0.06 & $0.65-0.78$ & 100 & 67.5 & 8.3 & 9.4 & 14.8 \\
\hline & $\begin{array}{l}\text { Nižbor } \\
\text { (average value per locality) }\end{array}$ & 0.69 & & & & & & & \\
\hline $14 / 001$ & Lobeč & 0.77 & 0.09 & $0.65-0.85$ & 55 & 9.3 & 7.4 & 13.8 & 69.5 \\
\hline 14/001B & Lobeč & 0.83 & 0.09 & $0.74-0.92$ & 100 & 10.4 & 8.7 & 15.1 & 65.8 \\
\hline \multirow[t]{2}{*}{$14 / 002$} & Lobeč & 0.73 & 0.08 & $0.63-0.81$ & 20 & 1.2 & 4.1 & 1.3 & 93.4 \\
\hline & $\begin{array}{l}\text { Lobeč (Kralupy) } \\
\text { (average value per locality) }\end{array}$ & 0.77 & & & & & & & \\
\hline
\end{tabular}

$\left(R_{r}=0.59 \%\right)$ resulted in a vitrinite $T-t$ path, that is very close to that provided by the AFTA data. According to the EASY\% $\mathrm{R}_{\mathrm{o}}$ algorithm, the sediment experienced a substantial and relatively fast heating soon after its deposition. The coalification corresponding to the level of sub-bituminous coals $\left(R_{r} \sim 0.40 \%\right)$ was largely accomplished during the Carboniferous-early Permian time, from 15-40 m.y. after the deposition of the peat.
It should be noted, however, that the EASY\% $\mathrm{R}_{\mathrm{o}}$ model also allows for an even faster coalification progress in which the VR values of $0.40 \% R_{r}$ would have been completed as soon as 4 m.y. after the peat deposition. The maximum palaeo-temperatures of around $85-90{ }^{\circ} \mathrm{C}$, and the respective VR values between $0.49-0.56 \% R_{n}$, were attained 35-40 m.y. after deposition (i.e. during the early Permian time). The modelling also indicates that the
RADNICE-OVČíN $R_{t}=0.59 \%$

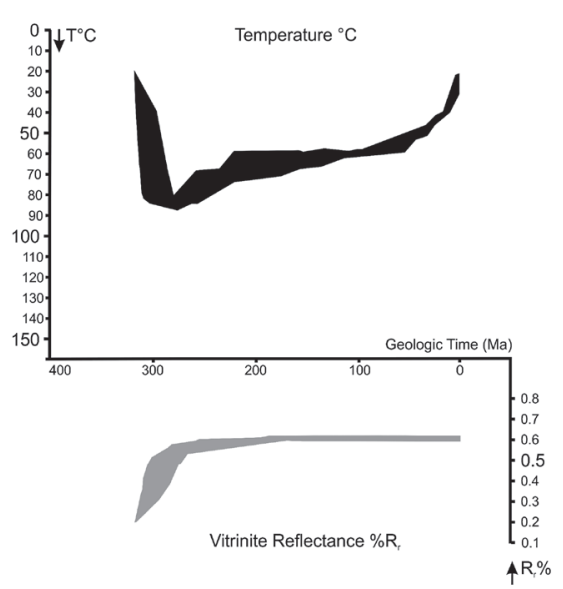

NIŽBOR $R_{t}=0.69 \%$

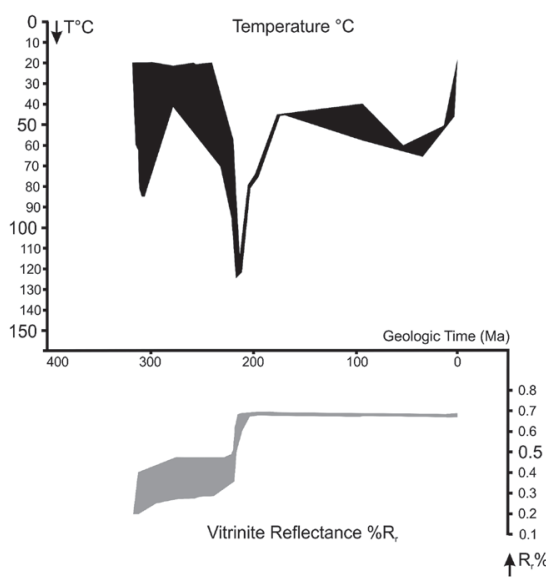

LOBEČ $R_{r}=0.77 \%$

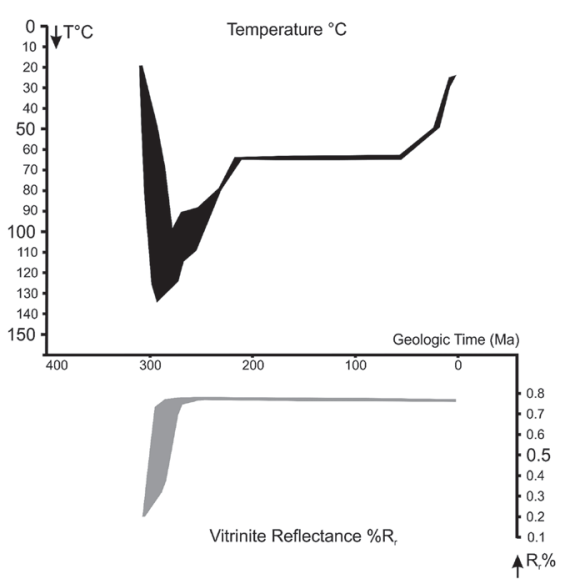

Figure 8. Thermal modelling of vitrinite reflectance using the model of Sweeney \& Burnham (1990). Variable input time-temperature history data are shown as black envelopes. Corresponding vitrinite reflectance values modelled with EASY\% $\mathrm{R}_{\mathrm{o}}$ software are shown in grey. Note a shift in maximum palaeo-temperatures between the samples that gradually increase from SW (Radnice-Ovčín) to NE (Lobeč). See the text for details. 
subsequent Mesozoic episode, when the sample resided for nearly $200 \mathrm{~m}$.y. in the zone of thermal stagnation at $60-75{ }^{\circ} \mathrm{C}$, had only a limited effect on the final VR value.

The modelling of elevated VR values that were ascertained at two other eastward localities (i.e. $0.69 \% R_{r}$ at Nižbor and $0.77 \% R_{r}$ at Lobeč), suggests maximum palaeo-temperatures of $125^{\circ} \mathrm{C}$ and $135^{\circ} \mathrm{C}$, respectively. This is in a general agreement with the results of AFTA modelling that indicate a complete annealing of apatite fission tracks of these two samples due to palaeotemperatures in excess of $\sim 120{ }^{\circ} \mathrm{C}$ before $200 \mathrm{Ma}$ and $\sim 260 \mathrm{Ma}$, respectively.

The modelling of the pre-annealing thermal evolution of the Nižbor sample allows for two different endmember $T$ - $t$ scenarios. Firstly, the sediment was rapidly and intensely heated to $\sim 80^{\circ} \mathrm{C}$ from 4 to $10 \mathrm{~m}$.y. after its deposition, in a way similar to the Radnice-Ovčín sample. During this early thermal event, which may have occurred during sedimentation of the Nýrany Member, the VR values were raised to around $0.40 \% R_{r}$, corresponding to sub-bituminous coal. This was followed by cooling to about $40{ }^{\circ} \mathrm{C}$, which was achieved about 40 m.y. after deposition (i.e. during the early Permian). Then, upon the subsequent second-stage heating that culminated around the Triassic-Jurassic transition, the maximum temperature of about $125^{\circ} \mathrm{C}$ was achieved. An alternative end-member scenario also exists that the sample experienced only a simple one-stage gradual heating during the Carboniferous to Triassic time, which culminated in maximum temperatures being attained at about $220 \mathrm{Ma}$. The vitrinite modelling also indicates that additional moderate heating, which occurred during the Cretaceous to Paleogene times (i.e. between $\sim 100-40 \mathrm{Ma}$ ), had very little, if any, impact on resulting VR values; the vitrinite had already been largely stabilized before $\sim 200 \mathrm{Ma}$.

For the Lobeč sample, the vitrinite modelling predicts steeply increasing palaeotemperatures during the first 20 m.y. after sediment deposition. This resulted in a significant VR increase so that the $R_{r}$ values of around $0.40 \%$ were achieved already during the Carboniferous Period. The EASY $\% \mathrm{R}_{\mathrm{o}}$ software predicts that these elevated VR values could have been attained extremely soon, about 2-4 m.y. after sediment deposition. The maximum palaeotemperatures of $\sim 135^{\circ} \mathrm{C}$ that largely induced the presentday VR values culminated during the early Permian (early Cisuralian) time, 270-290 Ma.

\section{Discussion}

The vitrinite reflectance modelling showed that the Carboniferous sediments were exposed to palaeo-temperatures, which ranged from $\sim 85{ }^{\circ} \mathrm{C}$ (Radnice-Ovčín) to $\sim 135^{\circ} \mathrm{C}$
(Lobeč). Although the kinetic modelling of vitrinite reflectance predicts an array of possible temporal scenarios, much of our data strongly indicate that maximum heating occurred soon after the deposition of Carboniferous strata, during the Carboniferous or early Permian times. Both apatite fission track and vitrinite reflectance modelling confirm a significant drop in sediment temperature before the onset of the Mesozoic thermal stagnation period and, a second prominent period of fast cooling that occurred during the Cenozoic Era. Remarkably similar palaeo-geothermal evolution has already been documented for Lower Palaeozoic and Neoproterozoic rocks of the Barrandian area, immediately to the south of the Carboniferous basins (Filip \& Suchý 2004; Suchý et al. 2007, 2015). This implies that the Carboniferous basins and their underlying geological units experienced a similar thermal evolution that was apparently controlled by regional geological processes.

Our data, though limited in extent, indicate that across the area, the coalification grade of Carboniferous coals slightly increased from SW to NE. Similar regional trends in coalification grade and palaeo-geothermal gradients have been already reported for Central-Western Bohemian Carboniferous deposits in some previous studies (e.g. Šafanda et al. 1990, Pešek 1996,), but the reason for these variations remain speculative. In general, palaeotemperatures recorded in Carboniferous sediments and regional changes across the area can be explained either by variations in the original thickness of stratigraphic overburden, or by variations in paleo-heat flow, or by a combination of both.

The present-day Carboniferous overburden does not exceed several tens of metres. The original thickness of Carboniferous and/or Permian overburden remains unknown since all three localities are situated along erosive margins of the basins where the removal of overlying sediments was probably intensive. The average thickness of preserved Carboniferous-Permian overburden extrapolated from the interior parts of the basins (i.e. about 700-900 m), even if combined with several hundreds of metres of hypothetical Cretaceous sedimentary cover (e.g. Holub et al. 1997, Martínek et al. 2017) is clearly insufficient to explain the thermal maturity of the Carboniferous sediments, at least under the present-day geothermal gradient $\left(\sim 30^{\circ} \mathrm{C} / \mathrm{km}\right.$ up to $35^{\circ} \mathrm{C} / \mathrm{km}$; Šafanda et al. 1990).

Indeed, only heat flows that were elevated in the past can provide a plausible mechanism to explain the maximum palaeo-temperatures as ascertained in the sediments. Dvořák (1989), Dvořák \& Paproth (1988) and Zwart $(1969,1975)$ have suggested palaeo-gradients as high as $200{ }^{\circ} \mathrm{C} / \mathrm{km}$ for some parts of the Variscan orogen in Central-Western Europe. Botor \& Anczkiewicz (2015), Littke et al. (1994) and Robert (1989) have also 
documented elevated Variscan heat flows for some coalbearing basins of Western Europe (see also Littke et al. 2000 and their discussion of the Permo-Carboniferous heat flow). Furthermore, the late Carboniferous to early Permian thermal climax has already been proposed to affect the diagenesis of Ordovician to Devonian sediments in the Barrandian area, immediately to the south of the Carboniferous basins (Franců et al. 1998, Glasmacher et al. 2002).

In this study, elevated Carboniferous-Permian heat flows are newly corroborated by vitrinite reflectance modelling, which suggests a steep palaeo-temperature rise soon after sediment deposition. The precise calculation of Carboniferous thermal gradients is, however, problematic as a substantial part of overlying Carboniferous strata and much of younger sedimentary cover were removed by erosion and its original thickness remains a matter of debate. Numerous stratigraphic breaks within the Carboniferous sequence, some of which lasted between 1-3.6 m.y. (e.g. Opluštil et al. 2016) provide additional uncertainties related to the original thickness of Carboniferous sediments that may have been deposited and/or eroded during these stratigraphic breaks. Nevertheless, simple conservative estimates show that the thermal gradients during the Carboniferous must have indeed been very high, probably around $200{ }^{\circ} \mathrm{C} / \mathrm{km}$, or even higher, similar to those of some present-day active rifts or geothermal fields (e.g. Palmer et al. 1975, Dornstadter et al. 1999).

The high Variscan heat flows could have been due to a number of factors including the thinning of the underlying lithosphere, abundant volcanic activity (e.g. Dvořák \& Paproth 1988) or hot igneous intrusions that penetrated into the subsurface. Klomínský (1994) has pointed out that the Variscan heat flow in the Bohemian Massif may have been substantially elevated by a number of granitic plutons of variable size, many of which were emplaced around 350-307 Ma (see also Henk et al. 2000 for their discussion on the role of granitoid intrusions in high-temperature metamorphism in the Variscan Orogen of Central Europe). However, granitic bodies are not present close to any of the localities examined. Gravity Bouguer anomalies around Kralupy nad Vltavou, close to the Lobeč locality (Sine 2000), may indicate the presence of plutonic bodies buried shallowly below the surface, but the age of these hypothetical intrusions, if any, remains unknown. Rhyolite and basaltic igneous intrusions of variable thicknesses are known to occur in the sediments of the Radnice Member and the Líně Formation (Pešek 2004). Abundant volcanic effusives intercalating with Carboniferous sediments also point to widespread synsedimentary volcanic activity. Unfortunately, volcanic centres, that produced these effusive deposits, are either fully covered by younger sediments or have been eroded

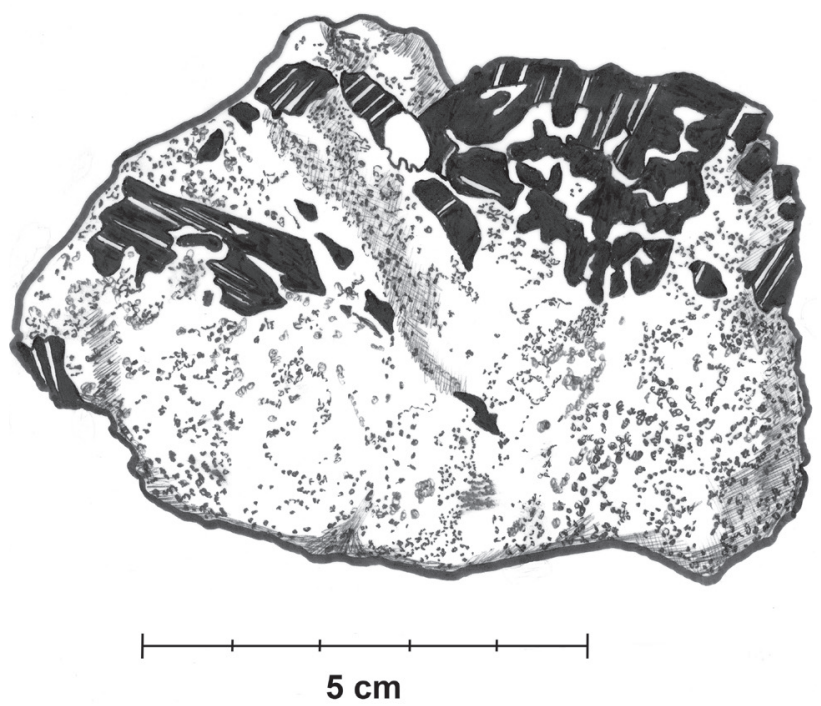

Figure 9. Drawing of a sample of redeposited coal clasts embedded in kaolinite-rich sandstone matrix (modified after black and white photograph from Pešek \& Sýkorová 2006). Note numerous cleats filled with clay minerals that cut through coaly fragments, perpendicular to its original bedding. These structural relationships evidence a very early onset and short duration of the coalification process; Kladno-Rakovník Basin.

in the past (e.g. Mašek 1973) so that their contribution to the ancient heat flow balance is difficult to quantify.

Except igneous intrusions or fossil volcanic activity, heat transport due to hot fluids migrating through fractures or along permeable horizons may have also been responsible, at least in part, for high palaeo-temperatures recorded in the Carboniferous sediments. These hot fluids may have contributed to the rapid coalification of organic matter enclosed in sedimentary strata (e.g. Daniels et al. 1990; Gayer et al. 1996, 1998; Marino et al. 2015; see also Duddy et al. 1998 and Hower \& Gayer 2002 for the reviews.). Whether the Carboniferous sediments have ever been exposed to heated fluids remains uncertain, but some geological observations may point to such a possibility. In particular, basal Carboniferous sediments in the Kladno-Rakovník basin were locally penetrated by quartz-carbonate veinlets that hosted aqueous inclusions of variable salinity. These palaeo-fluids were entrapped at temperatures of $156-187^{\circ} \mathrm{C}$, which were substantially higher than maximum burial temperatures inferred for the Carboniferous strata from other palaeo-thermometers (Zachariáš \& Pešek 2010, 2011). In a similar way, Suchý et al. (2017) have recently documented coaly particles yielding vitrinite reflectance values substantially elevated above the burial diagenetic backgrounds that were concentrated along goethite, gypsum, and jarosite-mineralized bedding planes and tectonic fractures in the Nýrany Member strata. They interpret this relationship as evidence that the Carboniferous sediments were exposed to hot 
mineralized fluids flowing through fractures or along permeable bedding planes. Similar examples of the diagenetic grade being escalated by fracture-bound migration of heated basinal fluids have already been recognized in Silurian and Devonian sediments of the nearby Barrandian area (Volk et al. 2002, Suchý et al. 2010).

Whatever the mechanisms driving elevated palaeotemperatures in the Carboniferous sequence, it follows that these strata must have been heated relatively soon after deposition when the sediments were still buried shallowly below the surface. This was clearly evidenced by numerous occurrences of redeposited clasts of subbituminous coals that occur at various stratigraphic levels of the Carboniferous sequence in the Plzeň and KladnoRakovník basins (Pešek 1978, Daněk et al. 2002). Many of these coaly clasts reveal abundant cleats oriented perpendicular to the original coal bedding. This strongly indicates that the coalification must have occurred prior to coal redeposition (Fig. 9). By combining structural observations with wider stratigraphic knowledge, some researchers have already concluded that the process of coalification occurred at a shallow burial level (Pešek \& Sýkorová 2006). These studies indicate that despite a thin sedimentary overburden, the peat-to-coal transformation proceeded extremely rapidly, with the coalification duration ranging from tens or several hundred thousands of years to a maximum of 2 m.y. Abundant stratigraphic hiatuses that were newly recognized within the Carboniferous succession (e.g. Opluštil et al. 2016) also indicate that the Carboniferous strata must have been periodically eroded, thus allowing for exhumation and erosion of some shallowly buried coal seams.

Our vitrinite reflectance modelling provides new independent evidence that VR values around $0.4 \% R_{r}$, indicative of a sub-bituminous coal rank, were attained very rapidly, as soon as 2 to 4 m.y. after peat deposition. An even more rapid increase and stabilization of vitrinite reflectance has been confirmed in other studies of natural open, fluid-rich geothermal systems and explained in terms of the effects of rapid thermal pulses that existed for only $10^{0}-10^{4}$ years (Barker 1991, Barker \& Pawlewicz 1994, Le Bayon et al. 2011). It should be noted, however, that the Burnham \& Sweeney (1989) model that we used for vitrinite modelling was restricted in that it did not allow for simulation of thermal events shorter than 1 m.y.

\section{Conclusions}

Our research using apatite fission track analysis and vitrinite reflectance kinetic modelling as complementary thermo-chronometers provides the following insights into the palaeo-geothermal history of Upper Carboniferous sediments of Central and Western Bohemia:
(1) During the Variscan Permo-Carboniferous thermal climax, geothermal gradients were extremely elevated $\left(\sim 200^{\circ} \mathrm{C} / \mathrm{km}\right.$ or even more), so that coalification proceeded rapidly and a substantial coal rank was reached close to the surface. Under these harsh geothermal conditions, coalification of the peat was completed within $\sim 2-4$ m.y. after deposition, or even earlier. During depositional hiatuses some shallowly buried coal seams were eroded and their remains were redeposited as intraclasts into younger Carboniferous sediments.

(2) The AFTA data shows that the sediments were exposed to maximum temperatures ranging from $\sim 75^{\circ} \mathrm{C}$ in the SW to more than $120^{\circ} \mathrm{C}$ in the NE, and these were attained prior to $\sim 200-260 \mathrm{Ma}$ (Permian to Early Jurassic time). This initial heating stage was followed by a period of regional cooling and thermal stability at temperatures between $\sim 50-75{ }^{\circ} \mathrm{C}$, lasting throughout much of the Mesozoic and Cenozoic eras. A second episode of accelerated cooling and erosion began at $\sim 20-40 \mathrm{Ma}$ and caused the present exposure of rocks at the surface.

(3) Vitrinite reflectance modelling using average VR values of $0.59 \% R_{r}$ in the $\mathrm{SW}$ and $0.77 \% R_{r}$ in the NE, corroborates the AFTA data and provides additional information on the pre-Jurassic evolution of the sediments. The modelling predicts heating at maximum temperatures ranging between $\sim 85-135^{\circ} \mathrm{C}$ that rapidly ascended during several millions of years after deposition of the sediments. This early heating caused a steep increase in vitrinite reflectance to values of $\sim 0.40-0.50 \% R_{r}$, which were largely achieved during the Carboniferous time.

(4) The cause for high heat flows that dominated during the Carboniferous-Permian periods was probably intense syn-sedimentary volcanism and/or igneous activity combined with heat transport provided by hot fluids that circulated through the strata.

\section{Acknowledgements}

A part of this research was supported by the Grant Agency of the Czech Republic (the project IAA210-12-2053). The support provided by OP RDE, MEYS, under the project "Ultra-trace isotope research in social and environmental studies using accelerator mass spectrometry" (Reg. No. CZ.02.1.01/0.0/0.0/1 6_019/0000728) and the institutional support RVO 67985831 of the Institute of Geology of the Czech Academy of Sciences are also to be acknowledged. Stanislav Opluštil (Charles University, Prague) introduced two of us (VS and JF) to the field during the early stage of the project. Jiři Bek (Institute of Geology CAS) kindly released his unpublished palynology data enabling us to clarify the stratigraphic position of the samples. Jan Novák is acknowledged for his IT support on the use of EASY\% $\%$ 
software. Our gratitude also goes to Lenka Borecká (Institute of Rock Structure and Mechanics CAS) for her patient assistance with the preparation of the diagrams. We especially thank R. Ferreiro Mählmann (Technisches Universität Darmstadt) and S. Opluštil (Charles University, Prague) whose insightful reviews and numerous constructive comments substantially improved the quality of the paper. Finally, J.D. Brooker (JKConsulting) kindly provided corrections on the use of the English language.

\section{References}

Aramowicz, A., Anczkiewicz, A.A. \& Mazur, S. 2006. Fissiontrack dating of apatite from the Góry Sowie Massif, Polish Sudetes, NE Bohemian Massif: implications for post-Variscan denudation and uplift. Neues Jahrbuch für Mineralogie, Abhandlungen 182(3), 221-229.

Armstrong, P.A. 2005. Thermochronology in Sedimentary Basins, 499-525. In Reiners, P.W. \& Ehlers, T.A. (eds) Low-Temperature Thermochronology: Techniques, Interpretations and Applications, Reviews in Mineralogy and Geochemistry 58. DOI 10.1515/9781501509575-021

Arne, D. \& Zentilli, M. 1994. Apatite Fission Track Thermochronology Integrated with Vitrinite Reflectance, 249-265. In Mukhopadhyay, P.K. \& Dow, W.P. (eds) Vitrinite Reflectance as a Maturity Parameter. Applications and Limitations. ACD Symposium Series 570. American Chemical Society.

Barbarand, J., Carter, A., Wood, I. \& Hurford, T. 2003. Compositional and structural control of fission-track annealing in apatite. Chemical Geology 198, 107-137. DOI 10.1016/S0009-2541(02)00424-2

BARKer, C.E. 1991. Implication for Organic Maturation Studies of Evidence for a geologically Rapid Increase and Stabilization of Vitrinite Reflectance at Peak Temperature: Cerro Prieto Geothermal system, Mexico. The American Association of Petroleum Geologists Bulletin 75(12), 1852-1863.

Barker, C.E. \& Pawlewicz, M.J. 1994. Calculation of Vitrinite Reflectance from Thermal Histories and Peak Temperatures, 216-229. In Muknopadhyay, P.K. \& Dow, W.G. (eds) Vitrinite Reflectance as a Maturity Parameter. Applications and Limitations, ACS Symposium Series 570. American Chemical Society, Washington DC.

Botor, D. \& Anczkiewicz, A.A. 2015. Thermal history of the Sabero Coalfield (Southern Cantabrian Zone, NW Spain) as revealed by apatite fission track analyses from tonstein horizons: implications for timing of coalification. International Journal of Earth Sciences 104, 1779-1793. DOI 10.1007/s00531-015-1169-z

Bray, R.J., Green, P.F. \& Duddy, I.R. 1992. Thermal history reconstruction using apatite fission track analysis and vitrinite reflectance: a case study from the UK East Midlands and Southern North Sea, 3-25. In Hardman, R.F. (ed.) Exploration Britain: Geological insights for the next decade. Geological Society London, Special Publication 67.

DOI 10.1144/GSL.SP.1992.067.01.01
Buntebarth, G. 1982. Geothermal history estimated from the coalification of organic matter. Tectonophysics 83(1-2), 101-108. DOI 10.1016/0040-1951(82)90010-5

Buntebarth, G. \& Stegena, L. (eds) 1986. Paleogeothermics. Evaluation of Geothermal Conditions in the Geological Past. Lecture Notes in Earth Sciences 5. 234 pp. Springer-Verlag, Berlin \& Heidelberg.

Burnham, A.K., Peters, K.E. \& SchenK, O. 2017. Evolution of Vitrinite Reflectance Models. Search and Discovery Article \#41982 (2017).

Burnham, A.K. \& Sweeney, J.J. 1989. A chemical kinetic model of vitrinite maturation and reflectance. Geochimica et Cosmochimica Acta 53, 2649-2657. DOI 10.1016/0016-7037(89)90136-1

Carlson, W.D., Donelick, R.A. \& Ketcham, R.A. 1999. Variability of Apatite Fission Track Annealing Kinetics I: Experimental Results. American Mineralogist 84, 1213-1223. DOI 10.2138/am-1999-0901

Čech, S., Klein, V., KŘiž, J. \& VAleČKA, J. 1980. Revision of the Upper Cretaceous stratigraphy of the Bohemian Cretaceous Basin. Věstník Ústředního ústavu geologického 55(5), 1213-1223.

Crowley, K.D., Cameron, M. \& Schaeffer, R. 1991. Experimental studies of annealing of etched fission tracks in fluorapatite. Geochimica et Cosmochimica Acta 55, 1449-1465. DOI 10.1016/0016-7037(91)90320-5

Dalla Torre, M., Ferreiro Mählmann, R. \& Ernst, W.G. 1997. Experimental study on the pressure dependence of vitrinite maturation. Geochimica et Cosmochimica Acta 61, 2921-2928. DOI 10.1016/S0016-7037(97)00104-X

Daněk, V., Pešek, J. \& Valterová, P. 2002. Coal clasts in the Bolsovian (Westphalian $\mathrm{C}$ ) sequence of the KladnoRakovník continental basin (Czech Republic): implication of the timing of maturation. Polish Geological Institute Special Paper 7, 63-78.

Daniels, E.J., Altaner, S.P. \& MarshaK, S. 1990. Hydrothermal alteration in anthracite from eastern Pennsylvania: Implications for mechanisms of anthracite formation. Geology 18, 247-250.

DOI 10.1130/0091-7613(1990)018<0247:HAIAFE $>2.3 . C O ; 2$

Danišík, M., Migón, P., Kuhlemann, J., Evans, N.J., Dunkl, I. \& Frisch, W. 2010. Thermochronological constraints on the long-term erosional history of the Karkonosze Mts., Central Europe. Geomorphology 117, 78-89. DOI 10.1016/j. geomorph.2009.11.010

Donelick, R.A. \& Ketcham, R.A. 1998. AFTSolve. Apatite Fission Track Modelling Software. Donelick Analytical Inc., Katy, Texas.

Donelick, R.A., Ketcham, R.A. \& Carlson, W.D. 1999. Variability of Apatite Fission Track Annealing Kinetics II: Crystallographic orientation effects. American Mineralogist 84, 1224-1234. DOI 10.2138/am-1999-0902

Dornstadter, J., Kappelmeyer, O. \& Welte, M. 1999. The geothermal potential in the Upper Rhine Graben valley, 77-85. In European Geothermal Conference Basel '99, September 28-30, 1999, Basel, Switzerland, Proceedings Volume 2.

Duddy, I.R., Green, P.F., Hegarty, K.A., Bray, R.J. \& O'Brien, 
G.W. 1998. Dating and duration of hot fluid flow events determined using AFTA $^{\circledR}$ and vitrinite reflectance-based thermal history reconstruction, 41-51. In PARnell, J. (ed.) Dating and Duration of Fluid Flow and Fluid-Rock Interaction. Geological Society London, Special Publication 144.

Dvoř́x, J. 1989. Anchimetamorfóza ve variském tektogenu střední Evropy - její vztah k tektogenezi. Věstník Ústředního ústavu geologického 64(1), 17-30.

DvořÁ, J. \& PAPRoth, E. 1988. Trends of the Variscan development near the SW border of the East European Platform. Zeitschrift für Angewandte Geologie, Band 34 (1988), Heft 12, 353-359.

Enkelmann, E. \& Garver, J.L. 2016. Low-temperature thermochronology applied to ancient settings. Journal of Geodynamics 93, 17-30. DOI 10.1016/j.jog.2015.11.001

Ferreiro Mählmann, R. \& Le Bayon, R. 2016. Vitrinite and vitrinite like solid bitumen reflectance in thermal maturity studies: Correlations from diagenesis to incipient metamorphism in different geodynamic settings. International Journal of Coal Geology 157, 52-73.

DOI 10.1016/j.coal.2015.12.008

Ferreiro Mählmann, R., Bozkaya, Ö., Potel, S., Le Bayon, R., ŠEgvić, B., Nieto, F. 2012. The pioneer work of Bernard Kübler and Martin Frey in very low-grade metamorphic terranes: paleo-geothermal potential of variation in Kübler Index/organic matter reflectance correlations. A review. Swiss Journal of Geosciences 105, 121-152.

DOI 10.1007/s00015-012-0115-3

Filip, J. \& Suchý, V. 2004. Thermal and tectonic history of the Barrandian Lower Paleozoic, Czech Republic: Is there a fission-track evidence for Carboniferous-Permian overburden and pre-Westphalian alpinotype thrusting? (Critical comments on the paper by Ulrich A. Glasmacher, Ulrich Mann and Günther A. Wagner). Bulletin of Geosciences 79(2), 107-112.

Franců, E., Mann, U., SuchÝ, V. \& Volk, H. 1998. Model of burial and thermal history of the Tobolka-1 borehole profile in the Prague basin. Acta Universitatis Carolinae-Geologica 42, 248-249.

Gallagher, K., Brown, R. \& Johnson, C. 1998. Fission track analysis and its applications to geological problems. Annual Review of Earth and Planetary Sciences 26, 519-572.

Gayer, R., Garven, G. \& Rickard, D. 1998. Fluid migration and coal-rank development in foreland basins. Geology 26(8), 679-682.

DOI 10.1130/0091-7613(1998)026<0679:FMACRD >2.3.CO;2

Gayer, R.A., PeŠEk, J., SÝKorovÁ, I. \& VAlterovÁ, P. 1996. Coal clasts in the upper Westphalian sequence of the South Wales coal basin: implications for timing of maturation and fracture permeability, 103-120. In GAYER, R. \& HARRIS, I. (eds) Coalbed Methane and Coal Geology. Geological Society London, Special Publication 109.

Glasmacher, U.A., Mann, U. \& Wagner, G.A. 2002. Thermotectonic evolution of the Barrandian, Czech Republic, as revealed by apatite fission-track analysis. Tectonophysics 359, 381-402. DOI 10.1016/S0040-1951(02)00538-3

Gleadow, A.J.W., Belton, D.X., Kohn, B.P. \& Brown, R.W. 2002.
Fission track dating of phosphate minerals and the thermochronology of apatite. Reviews in Mineralogy and Geochemistry 48, 579-630. DOI 10.2138/rmg.2002.48.16

Green, P.J. \& DudDy, I.R. 2012. Thermal history reconstruction in sedimentary basins using apatite fission-track analysis and related techniques, 65-104. In HARRIS, N.B. \& DudDY, I.R. (eds) Analyzing the thermal history of sedimentary basins: methods and case studies. Society for Sedimentary Geology Special Publication 103.

Green, P.F., Duddy, I.R. \& Hegarty, K.A. 2002. Quantifying exhumation from apatite fission-track analysis and vitrinite reflectance data: precision, accuracy and latest results from the Atlantic margin of NW Europe, 331-354. In Doré, A.G., Cartwight, J., Stoker, M.S., Turner, J.P. \& White, N. (eds) Exhumation of the North Atlantic Margin: Timing, Mechanisms and Implication for Petroleum Exploration. Geological Society London, Special Publicaton 196.

Hartkopf-Fröder, C., Königshof, P., Littke, R. \& SchwarzBAUER, J. 2015. Optical thermal maturity parameters and organic geochemical alteration at low grade diagenesis to anchimetamorphism. International Journal of Geology 150, 74-119. DOI 10.1016/j.coal.2015.06.005

Havlena, V. 1964. Geologie uhelných ložisek 2. 438 pp. Nakladatelství Československé Akademie věd, Praha.

HavlenA, V. 1982. Limnické pánve permokarbonu Českého masivu - geneze, třídění, vyplňování a zlomová tektonika, 37-44. In Sborník IV. uhelně geologické konference Přirodovědecké fakulty Univerzity Karlovy. Univerzita Karlova, Praha.

HeJ, E., Sekyra, G. \& Friedl, G. 2003. Fission-track dating of the south-eastern Bohemian massif (Waldviertel, Austria): thermochronology and long-term erosion. International Journal of Earth Sciences 92, 677-690.

DOI 10.1007/s00531-003-0342-y

Hejl, E., Coyle, D., Nand, L., Van Den Haute, P. \& Wagner, G.A. 1997. Fission-track dating of the western border of the Bohemian massif: thermochronology and tectonic implications. Geologische Rundschau 86, 210-219. DOI 10.1007/s005310050133

Henk, A., Blanckenburg, F. von, Finger, F., Schaltegger, U. \& Zulauf, G. 2000. Syn-convergent high-temperature metamorphism and magmatism in the Variscides: a discussion of potential heat sources, 387-399. In Franke, W., HAAK, V., Oncken, O. \& TAnner, D. (eds) Orogenic Processes: Quantification and Modelling in the Variscan Belt. Geological Society London, Special Publication 179.

Holub, V. 1982. Explanatory notes to the lithotectonic profile of the Permo-Carboniferous basins of the Central Bohemian region (ČSSR). In LÜTZNER, H. \& SchwAB, H.G.L. (eds) Tectonic regime of molasse epochs. Zentralinstitut für Physics der Erde, Potsdam.

Holub, V. \& Obrhel, J. 1967. Profil karbonskou pánví u Malých Př́lep ssv od Berouna. Ćasopis pro mineralogii a geologii 12(3), 271-276.

Holub, V., Eliáš, M., Hrazdíra, P. \& Franců, J. 1997. Geological research into gas sorbed in the coal seams of the Carboniferous in the Mšeno-Roudnice Basin, Czech Re- 
public, 409-423. In GAYER, R. \& Pešek, J. (eds) European Coal Geology and Technology. Geological Society London, Special Publication 125.

Hood, A., Gutjahr, C.C. \& Heacock, R.L. 1975. Organic metamorphism and the generation of petroleum. American Association of Petroleum Geologists Bulletin 59, 986-996.

Hower, J.C. \& GAYer, R.A. 2002. Mechanisms of coal metamorphism: case studies from Paleozoic coalfields. International Journal of Coal Geology 50, 215-245. DOI 10.1016/S0166-5162(02)00119-2

HuANG, W.L. 1996. Experimental study of vitrinite maturation: Effect of temperature, time, pressure, water, and hydrogen index. Organic Geochemistry 24, 233-241. DOI 10.1016/0146-6380(96)00032-0

Hunt, J.M. 1979. Petroleum Geochemistry and Geology. 617 pp. W.H. Freeman, San Francisco.

Hurford, A.J. \& GREEN, P.F. 1982. A user's guide to fission-track dating calibration. Earth and Planetary Science Letters 59, 343-354. DOI 10.1016/0012-821X(82)90136-4

Hurford, A.J. \& Green, P.F. 1983. The Zeta calibration of fission-track dating. Chemical Geology 31, 285-317. DOI 10.1016/S0009-2541(83)80026-6

ICCP 1998. The new vitrinite classification (ICCP system 1994). Fuel 77, 349-358. DOI 10.1016/S0016-2361(98)80024-0

ICCP 2001. The new inertinite classification (ICCP system 1994). Fuel 80, 459-471. DOI 10.1016/S0016-2361(00)00102-2

International Classification of In-Seam Coals 1998. 14pp. United Nations, New York \& Geneva.

ISO 7404-3 2009. Methods for the Petrographic Analysis of Coal - Part 3: Method of Determining Maceral Group Composition. 14 pp. International Organization for Standardization, Geneva, Switzerland.

ISO 7404-5, 2009. Methods for the Petrographic Analysis of Coal-Part 5: Method of determining microscopically the reflectance of vitrinite. $14 \mathrm{pp}$. International Organization for Standardization, Geneva, Switzerland.

Ketcham, R.A. \& Apatite to Zircon, Inc. 2007. HefTy software version 1.4.

Ketcham, R.A., Donelick, R.A. \& Carlson, W.D. 1999. Variability of Apatite Fission Track Annealing Kinetics III: Extrapolation to Geological Time Scales. American Mineralogist 84, 1235-1255. DOI 10.2138/am-1999-0903

Ketcham, R.A., Donelick, R.A. \& Donelick, M.B. 2000. AFTSolve: A Program for Multi-kinetic Modelling of Apatite Fission-track Data. Geological Materials Research 2, 1-32.

Ketcham, R.A., Donelick, R.A. \& Donelick, M.B. 2003. AFTSolve: A program for multi-kinetic modelling of apatite fission-track data. American Mineralogist 88, 929.

Ketcham, R.A., Carter, A., Donelick, R.A., Barbarand, J. \& Hurford, A.J. 2007. Improved measurement of fissiontrack annealing in apatite using c-axis projection. American Mineralogist 92 (5-6), 799-810. DOI 10.2138/am.2007.2281

KLomínsKÝ, J. (ed.) 1994. Geological Atlas of the Czech Republic, Stratigraphy. 17 maps. Czech Geological Survey, Praha.

KuKaL, Z. 1983. Granitoidové plutony byly hlavním zdrojem živců permokarbonských sedimentů. Časopis pro mineralogii a geologii 28(4), 423-428.
Laslett, G.M., Green, P.F., Duddy, I.R. \& Gleadow, A.J.W. 1987. Thermal annealing of fission tracks in apatite 2 . A quantitative analysis. Chemical Geology (Isotope Geoscience Section) 65, 1-13. DOI 10.1016/0168-9622(87)90057-1

Le Bayon, R., Adam, C. \& Ferreiro Mählmann, R. 2012. Experimentally determined pressure effect on vitrinite reflectance at 450 degrees C. International Journal of Geology 92, 69-81. DOI 10.1016/j.coal.2011.12.007

Le Bayon, R., Brey, G.P., Ernst, W.G. \& Ferreiro MählMANN, R. 2011. Experimental kinetic study of organic matter maturation: Time and pressure effect on vitrinite reflectance at $400{ }^{\circ} \mathrm{C}$. Organic Geochemistry 42, 340-355. DOI 10.1016/j.orggeochem.2011.01.011

Lisker, F., Ventura, B. \& Glasmacher, A. 2009. Apatite thermochronolgy in modern geology, 1-23. In Lisker, F., Ventura, B. \& Glasmacher, U.A. (eds) Thermochronological Methods: From Palaeotemperature Constraints to Landscape Evolution Models. Geological Society London, Special Publication 324.

Littke, R., Büker, C., Hertle, M., Karg, H., StroetmannHeinen, V. \& Oncken, O. 2000. Heat flow evolution, subsidence and erosion in the Rheno-Hercynian orogenic wedge of central Europe, 231-255. In Franke, W., HaAK, V., Oncken, O. \& Tanner, D. (eds) Orogenic Processes: Quantification and Modelling in the Variscan Belt. Geological Society London, Special Publication 179.

Littke, R., Büker, C., Lückge, A., Sachsenhofer, R.F. \& Welte, D.H. 1994. A new evaluation of palaeo-heat flows and eroded thicknesses for the Carboniferous Ruhr Basin, Western Germany. International Journal of Coal Geology 26, 155-183. DOI 10.1016/0166-5162(94)90009-4

Lojka, R., Rosenau, N.A., Sidorinová, T. \& Strnad, L. 2016. Architecture, paleosols and cyclicity of the Middle-Late Pennsylvanian proximal fluvial system (Nýřany Member, Pilsen Basin, Czech Republic). Bulletin of Geosciences 91(1), 111-140. DOI 10.3140/bull.geosci.1509

Lopatin, N.V. 1971. Temperature and geologic time as factors in coalification. Izvestia Akademii Nauk SSSR Ser. Geol. 3, 95-106. [in Russian]

MaLÁn, O. 1985. Some petrological properties of the Chotíkov coal-field (Plzeň Basin, Czechoslovakia). Folia Musei rerum naturalis Bohemiae occidentalis - Geologica 22, 1-32.

MaLkovskÝ, M. 1979. Tektogeneze platformního pokryvu Českého masívu. Knihovna Ústředního ústavu geologického 53, $1-176$.

MalkovskÝ, M. 1987. The Mesozoic and Tertiary basins of the Bohemian Massif and their evolution. Tectonophysics 137, 31-42. DOI 10.1016/0040-1951(87)90311-8

Marino, J., Marshak, S. \& Mastalerz, M. 2015. Evidence for stratigraphically controlled paleogeotherms in the Illinois Basin based on vitrinite-reflectance analysis: Implications for interpreting coal-rank anomalies. American Association of Petroleum Geologists Bulletin 99(10), 1803-1825. DOI 10.1306/04151513001

MartíneK, K., PeŠeK, J. \& Opluštil, S. 2017. Significant hiatuses in the terrestrial Late Variscan Central and Western Bohemian 
basins (Late Pennsylvanian-Early Cisuralian) and their possible tectonic and climatic links. Geologica Carpathica 68(3), 269-281. DOI 10.1515/geoca-2017-0019

MAŠEK, J. 1973. Vulkanické produkty středočeského karbonu. Sborník geologických věd, Geologie 40, 73-104.

McCann, T., Pascal, C., Timmermann, M.J., Krzywiec, P., López-Gómez, J., Wetzel, A., Krawczyk, C.M., Rieke, H. \& LAmArche, J. 2006. Post-Variscan (end Carboniferous - Early Permian) basin evolution in Western and Central Europe, 355-388. In Gee, D.G. \& Stephenson, R.A. (eds) European Lithosphere Dynamics. Geological Society London, Memoir 32. DOI 10.1144/GSL.MEM.2006.032.01.22

Mísař, Z., Dudek, A., Havlena, V. \& Weiss, J. 1983. Geologie ČSSR I. Český masív. 333 pp. Státní pedagogické nakladatelství, Praha.

Morrow, D.W. \& Issler, D.R. 1993. Calculation of Vitrinite Reflectance from Thermal Histories: A Comparison of Some Methods. American Association of Petroleum Geologists Bulletin 44(4), 610-624.

Mukhopadhyay, P.K. 1992. Maturation of organic matter as revealed by microscopic methods: Applications and limitations of vitrinite reflectance, and continuous spectral and pulsed laser fluorescence spectroscopy, 435-510. In Wolf, K.H. \& Chilingarian, G.V. (eds) Diagenesis III, Developments in Sedimentology 47. Elsevier.

Naeser, C.W., Naeser, N.D. \& McCulloh, T.H. 1989. The application of fission track dating to the depositional and thermal history of rocks in sedimentary basins, 157-180. In NaEser, N.D. \& McCulloh, T.H. (eds) Thermal History of Sedimentary Basins - Methods and Case Studies. SpringerVerlag, New York.

NĚMEJC, J. 1953. Úvod do floristické stratigrafie kamenouhelných oblastí v ČSR. 173 pp. Nakladatelství ČSAV, Praha.

Nielsen, S.B., Clausen, O.R. \& McGregor, E. 2017. basin\%R: A vitrinite reflectance model derived from basin and laboratory data. Basin Research 29, 515-536. DOI $10.1111 /$ bre. 12160

Opluštil, S. 2005. Evolution of the Middle Westphalian river valley drainage system in central Bohemia (Czech Republic) and its palaeographic implication. Palaeogeography, Palaeoclimatology, Palaeoecology 222, 223-258. DOI 10.1016/j.palaeo.2005.03.016

Opluštil, S., Martínek, K. \& Tasáryová, Z. 2005. Facies and architectural analysis of fluvial deposits of the Nýřany Member and the Týnec Formation (Westphalian D Barruelian) in the Kladno-Rakovník and Pilsen basins. Bulletin of Geosciences 80(1), 45-66.

Opluštil, S., PšeničKa, J., Libertín, M., Bashforth, A.R., ŠImŮNeK, Z., DrÁBKová, J. \& DAŠKovÁ, J. 2009. A Middle Pennsylvanian (Bolsovian) peat-forming forest preserved in situ in volcanic ash of the Whetstone Horizon in the Radnice Basin, Czech Republic. Review of Palaeobotany and Palynology 155, 234-274.

DOI 10.1016/j.revpalbo.2009.03.002

Opluštil, S., Schmitz, M., Cleal, C.J. \& Martínek, K. 2016. A review of the Middle-Late Pennsylvanian west European regional substages and floral biozones, and their correlation to the Geological Time Scale based on new U-Pb ages. EarthScience Reviews 154, 301-335.

DOI 10.1016/j.earscirev.2016.01.004

Palmer, T.D., Howard, J.H. \& Lande, D.P. (eds) 1975. Geothermal development of the Salton trough, California and Mexico. 45 pp. Livermore Laboratory, University of California.

PAŠEK, J. 1988. Coalification in the Plzeň Basin from the viewpoint of reflectance, 175-179. In PEŠEK, J. \& VOZÁR, J. (eds) Coal-Bearing Formations of Czechoslovakia. Dionýz Štúr Institute of Geology, Bratislava.

PAŠEK, J. \& URBAN, M. 1990 The tectonic evolution of the Plzeň basin (Upper Carboniferous, West Bohemia): a review and interpretation. Folia Musei rerum naturalis Bohemiae occidentalis - Geologica 32, 1-56.

PešEK, J. 1978. Erosion and clastic dikes in coal seams of the central Bohemian basins and their significance for determination of plant substance coalification. Folia Musei rerum naturalis Bohemiae occidentalis - Geologica 12, 1-34.

PešEk, J. 1996. Geology of Central Bohemian Upper Paleozoic Sedimentary Basins. 95 pp. Czech Geological Survey, Praha.

PEŠEK, J. (ed.) 2001. Geologie a ložiska svrchnopaleozoických limnických pánví České republiky. 244 pp. Český geologický ústav, Praha.

PešEK, J. 2004. Late Paleozoic limnic basins and coal deposits of the Czech Republic. Folia Musei rerum naturalis Bohemiae occidentalis - Geologica, Edittio Specialis 1, 1-188.

Pešek, J. \& MartíneK, K. 2012. Observations concerning the thickness of rocks eroded between the Cambrian and Bolsovian (= Westphalian C) in central and western Bohemia. Folia Musei rerum naturalis Bohemiae occidentalis - Geologica et Paleobiologica 46, 1-14.

Pešex, J. \& Sivek, M. 2016. Coal-bearing basins and coal deposits of the Czech Republic. 208 pp. Czech Geological Survey, Prague.

PeŠEK, J. \& SÝkorová, I. 2006. A review of the timing of coalification in the light of coal seam erosion, clastic dykes and coal clasts. International Journal of Coal Geology 66, 13-34. DOI 10.1016/j.coal.2005.05.010

Pešek, J., Opluštil, S., Kumpera, O., Holub, V. \& Skoček, V. (eds) 1998. Paleogeographic Atlas of Late Paleozoic and Triassic Formations of the Czech Republic. 56 pp. 41 app. Czech Geological Survey, Prague.

Pickel, W., Kus, J., Flores, D., Kalaitzidis, S., Christianis, K., Cardott, B.J., Misz-Kennan, M., Rodrigues, S., Hentschel, A., Hamor-Vido, M., Crosdale, P. \& Wagner, N. 2017. Classification of liptinite - ICCP System 1994. International Journal of Coal Geology 169, 40-61. DOI 10.1016/j.coal.2016.11.004

Potel, S., Maison, T., Maillet, M., Sarr, A.C., Doublier, M.P., Trullenque, G. \& Ferreiro Mählmann, R. 2016. Reliability of very low-grade metamorphic methods to decipher basin evolution: Case study from the Markstein basin (Southern Vosges, NE France). Applied Clay Science 134, 175-185. DOI 10.1016/j.clay.2016.10.003

PovOndra, P. \& Ulrych, J. 1988. Základy úpravnictví a separace minerálů. 105 pp. Státní pedagogické nakladatelství, Praha. 
Price, L.C. 1983. Geologic time as a parameter in organic metamorphism and vitrinite reflectance as an absolute paleogeothermometer. Journal of Petroleum Geology 6, 5-38. DOI 10.1111/j.1747-5457.1983.tb00260.x

Robert, P. 1988. Organic Metamorphism and Geothermal History. Microscopic Study of Organic Matter and Thermal Evolution of Sedimentary Basins. 311 pp. Elf-Aquitaine and D. Reidel Publ. Company, Dordrecht.

Robert, P. 1989. The thermal setting of Carboniferous basins in relation to the Variscan orogeny in Central and Western Europe. International Journal of Coal Geology 13, 171-206. DOI 10.1016/0166-5162(89)90094-3

ŠAfanda, J., ŽÁkovÁ, J. \& Buntebarth, G. 1990. Temperature Paleogradient Estimations in the Central Bohemian Basin. Studia Geophisica et Geodetica 34, 208-219. DOI 10.1007/BF02295927

SINE 2000. Gravimetrická mapa České republiky úplných Bougerových anomálii $\left(2.67 \mathrm{~g} / \mathrm{cm}^{-3}\right), 1: 200$ 000, list M-33XV Praha. MS Geofyzika, a. s., Brno.

SKоČEK, V. 1976. Regional and geological interpretation of organic matter coalification in the Late Palaeozoic sediments of the Bohemian Massif. Věstník Ústředniho ústavu geologického 51, 13-25.

Sobczyk, A., Danišík, M., Alekssandrowski, P. \& Anckiewicz, A. 2015. Post-Variscan cooling history of the central Western Sudetes (NE Bohemian Massif, Poland) constrained by apatite fission-track and zircon (U-Th)/He thermochronology. Tectonophysics 649, 47-57.

DOI 10.1016/j.tecto.2015.02.021

Storzer, D., \& Selo, M. 1984. Toward a New Tool in Hydrocarbon Resource Evaluation: The Potential of the Apatite Fission-Track Chrono-Thermometer, 89-110. In DurAND, B. (ed.) Thermal Phenomena in Sedimentary Basins. Edition Technip, Paris.

Suarez-Ruiz, I., Flores, D., Mendonca, J.G. \& Hackley, P.C. 2012. Review and update of the application of organic petrology: Part 1, geological applications. International Journal of Coal Geology 99, 54-112.

DOI 10.1016/j.coal.2012.02.004

Suchy, V., Frey, M. \& Wolf, M. 1997. Vitrinite reflectance and shear-induced graphitization in orogenic belts: A case study from the Kandersteg area, Helvetic Alps, Switzerland. International Journal of Coal Geology 34, 1-20. DOI 10.1016/S0166-5162(97)00018-9

Suchy, V., Dobes, P., Filip, J., Stejskal, M., Zeman, A. 2002. Conditions for veining in the Barrandian Basin (Lower Paleozoic), Czech Republic: evidence from fluid inclusion and apatite fission track analysis. Tectonophysics 348, 25-50. DOI 10.1016/S0040-1951(01)00248-7

Suchý, V., Dobeš, P., Sýkorová, I., Machovič, V., Stejskal, M., Kroufek, J., Chudoba, J., MatěJovský, L., Havelcová, M. \& MatysovÁ, P. 2010. Oil-bearing inclusions in vein quartz and calcite and, bitumens in veins: Testament to multiple phases of hydrocarbon migration in the Barrandian basin (lower Palaeozoic), Czech Republic. Marine and Petroleum Geology 27, 285-297. DOI 10.1016/j.marpetgeo.2009.08.017

Suchý, V., Sandler, A., Slobodní, M., SÝkorová, I., Filip, J.,
MelKa, K. \& Zeman, A. 2015. Diagenesis to very low-grade metamorphism in lower Palaeozoic sediments: A case study from deep borehole Tobolka 1, the Barrandian Basin, Czech Republic. International Journal of Coal Geology 140, 41-62. DOI 10.1016/j.coal.2014.12.015

Suchý, V., SÝkorová, I., Melka, K., Filip, J. \& Machovič, V. 2007. Illite "crystallinity", maturation of organic matter and microstructural development associated with lowest-grade metamorphism of Neoproterozoic sediments in the Teplá-Barrandian unit, Czech Republic. Clay Minerals 42, 503-526. DOI 10.1180/claymin.2007.042.4.08

SuchÝ, V., SÝkorová, I., Zachariáš, J., Filip, J., Machovič, V. \& LAPČÁK, L. 2017. Hypogene features in sandstones: an example from Carboniferous basins of central-western Bohemia, Czech Republic, 313-328. In Kuimchouk, A., Palmer, A., De Waele, J. \& Audra, P. (eds) Hypogene Karst Regions and Caves of the World. Springer-Verlag. DOI 10.1007/978-3-319-53348-3 20

Sweeney, J.J. \& Burnham, A.K. 1989. Evaluation of a Simple Model of Vitrinite Reflectance Based on Chemical Kinetics. American Association of Petroleum Geologists Bulletin 74(10), 1559-1570.

Tagami, T. \& O'Sullivan, P.B. 2005. Fundamentals of FissionTrack Thermochronology, 19-47. In ReInERs, P.W. \& EHLERs, T.A. (eds) Low-Temperature Thermochronology: Techniques, Interpretations and Applications. Reviews in Mineralogy and Geochemistry 58.

Taylor, G.H., Teichmüller, M., Davis, A., Diessel, C.F.K., Littke, R. \& Robert, P. 1998. Organic Petrology. 704 pp. Gebrüder Bortraeger, Berlin.

Teichmüller, M. 1987. Organic material and very low-grade metamorphism, 114-161. In FREY, M. (ed.) Low Temperature Metamorphism. Blackie, Glasgow.

Thomson, S.N. \& Zen, A. 2000. Fission-track thermochronology of the Ruhla Crystalline Complex: new constraints on the post-Variscan thermal evolution of the NW Saxo-Bohemian Massif. Tectonophysics 324(1-2), 17-35.

DOI 10.1016/S0040-1951(00)00113-X

Tissot, B.P. \& Welte, D.H. 1984. Petroleum Formation and Occurrence. 699 pp. Springer-Verlag, New York.

DOI 10.1007/978-3-642-87813-8

Tobin, C.R. \& Claxton, L. 2000. Multidisciplinary thermal maturity studies using vitrinite reflectance and fluid inclusion microthermometry: A new calibration of old technique. American Association of Petroleum Geologists Bulletin 84, 1647-1665.

UliČNÝ, D. \& Franců, J. 1996. Subsidence history and tectonic regime of the Bohemian Cretaceous basin: a preliminary note, p. 45. In Sedimentární geologie v České republice, Abstrakty, 23. a 24. ledna 1996 v Praze. Geologická sekce Př́rodovědecké fakulty Univerzity Karlovy, Praha.

VamvaKa, A., Siebel, W., Chen, F. \& Rohmüller, J. 2013. Apatite fission-track dating and low-temperature history of the Bavarian Forest (southern Bohemian Massif). International Journal of Earth Sciences 103(1), 103-119.

DOI 10.1007/s00531-013-0945-x

VenturA, B. \& Lisker, F. 2003. Long-term landscape evolution 
of the northeastern margin of the Bohemian Massif: apatite fission-track data from the Erzgebirge (Germany). International Journal of Earth Sciences 92, 691-700.

DOI 10.1007/s00531-003-0344-9

Volk, H., Horsfield, B., Mann, U. \& SuchÝ, V. 2002. Variability of petroleum inclusions in veins fossil and vug cements a geochemical study in the Barrandian Basin (Lower Palaeozoic, Czech Republic). Organic Geochemistry 33, 1319-1341. DOI 10.1016/S0146-6380(02)00181-X

Wagner, G.A. \& Van Den Haute, P. 1992. Fission-Track Dating. 453 pp. Ferdinand Encke Verlag, Stuttgart. DOI 10.1007/978-94-011-2478-2

Waples, D.W. 1980. Time and temperature in petroleum formation: application of Lopatin's method to petroleum exploration. American Association of Petroleum Geologists Bulletin 64, 916-926.

Waples, D.W. 1989. Maturity Modeling of Sedimentary Basins: Approaches, Limitations and Prediction of Future Developments, 181-193. In Cross, T.A. (ed.) Quantitative Dynamic Stratigraphy. Prentice Hall, New Jersey.

Wood, D.A. 1988. Relationship between thermal maturation indices calculated using Arrhenius equations and Lopatin method: implications for petroleum exploration. American Association of Petroleum Geologists Bulletin 72, 115-134.

ZACHARIÁš, J. \& PEŠEK, J. 2010. Nepřímé indicie pro stanovení stáří polymetalické mineralizace strúbrského rudního revíru. Bulletin Mineralogicko-petrologického oddělení Národního muzea (Praha) 18(2), 109-111.
Zachariáš, P. \& PešEK, J. 2011. Fluid inclusions study of carbonate-dominated veinlets from coal seam and rocks of the Central and Western Bohemian basins, Czech Republic. Acta Geodynamica et Geomaterialia 8(2), 133-143.

ŽÁK, J., SvoJTKA, M. \& OpluŠTIL, S. 2018. Topographic inversion and changes in the sediment routing systems in the Variscan orogenic belts as revealed by detrital zircon and monazite updates U-Pb geochronology in post-collisional continental basins. Sedimentary Geology 377, 63-81.

DOI 10.1016/j.sedgeo.2018.09.008

Zeman, A., Suchy, V., Stejskal, M., Janku, J., Cermak, J. \& TureK, K. 2000. Migration of fluids controlled by equidistant fracture systems: an example from Central Europe (Czech Republic, Slovakia and Austria). Journal of Geochemical Exploration 69/70, 499-504. DOI 10.1016/S0375-6742(00)00035-2

Ziegler, P.A. 1990. Geological Atlas of Western and Central Europe. Shell, The Hague.

Ziegler, P.A., Cloetingh, S. \& Van Wees, J.D. 1999. Dynamics of intra-plate compressional deformations: the Alpine foreland and other examples. Tectonophysics 252, 7-59. DOI 10.1016/0040-1951(95)00102-6

Zwart, H.J. 1969. Metamorphic facies series in the European orogenic belts and the bearing on the causes of orogeny. Geological Association of Canada Special Paper 5, 7-15.

Zwart, H.J. 1975. The Hercynian orogeny in Europe. Progress in Geodynamics. 84 pp. Royal Netherlands Academy of Arts and Science. Amsterdam. 